\title{
Translational upregulation of folate receptors is mediated by homocysteine via RNA-heterogeneous nuclear ribonucleoprotein $\mathrm{E} 1$ interactions
}

\author{
Aśok C. Antony, ${ }^{1}$ Ying-Sheng Tang, ${ }^{1}$ Rehana A. Khan, ${ }^{1}$ Mangatt P. Biju, ${ }^{1}$ Xiangli Xiao, ${ }^{1}$ \\ Qing-Jun Li, ${ }^{1}$ Xin-Lai Sun, ${ }^{1}$ Hiremagalur N. Jayaram, ${ }^{2}$ and Sally P. Stabler ${ }^{3}$ \\ ${ }^{1}$ Division of Hematology-Oncology, Department of Medicine, and \\ ${ }^{2}$ Department of Biochemistry and Molecular Biology, Indiana University School of Medicine, and the Richard L. Roudebush \\ Veterans Affairs Medical Center, Indianapolis, Indiana, USA \\ ${ }^{3}$ Division of Hematology, Department of Medicine, University of Colorado Health Sciences Center, Denver, Colorado, USA
}

\begin{abstract}
Cellular acquisition of folate is mediated by folate receptors (FRs) in many malignant and normal human cells. Although FRs are upregulated in folate deficiency and downregulated following folate repletion, the mechanistic basis for this relationship is unclear. Previously we demonstrated that interaction of an 18-base cis-element in the $5^{\prime}$-untranslated region of FR mRNA and a cystolic transfactor (heterogeneous nuclear ribonucleoprotein E1 [hnRNP E1]) is critical for FR synthesis. However, the molecular mechanisms controlling this interaction, especially within the context of FR regulation and folate status, have remained obscure. Human cervical carcinoma cells exhibited progressively increasing upregulation of FRs after shifting of folate-replete cells to low-folate media, without a proportionate rise in FR mRNA or rise in hnRNP E1. Translational FR upregulation was accompanied by a progressive accumulation of the metabolite homocysteine within cultured cells, which stimulated interaction of the FR mRNA cis-element and hnRNP E1 as well as FR biosynthesis in a dose-dependent manner. Abrupt reversal of folate deficiency also led to a rapid parallel reduction in homocysteine and FR biosynthesis to levels observed in folate-replete cells. Collectively, these results suggest that homocysteine is the key modulator of translational upregulation of FRs and establishes the linkage between perturbed folate metabolism and coordinated upregulation of FRs.

J. Clin. Invest. 113:285-301 (2004). doi:10.1172/JCI200411548.
\end{abstract}

\section{Introduction}

Folates are critical for the perpetuation of one-carbon metabolism and DNA synthesis (1), and folate receptors (FRs) have been shown to mediate the cellular uptake of the physiological folate 5-methyltetrahydrofolate in several malignant and normal cells (reviewed in ref. 2). The native membrane-associated FR glycoprotein of cervical cancer $\left(\mathrm{HeLa}-\mathrm{IU}_{1}\right)$ cells is hydrophobic and binds a significant amount of Triton X-100 detergent upon solubilization (3). This hydrophobicity is conferred primarily by its glycosylphosphatidylinositol (GPI)-anchored tail, which can be cleaved off by GPI-specific phospholipase $\mathrm{C}$ and/or $\mathrm{D}$ to give rise to a hydrophilic species. Alternatively, endoproteolytic cleavage of the GPI anchor and the C-terminal end of

Received for publication October 13, 2000, and accepted in revised form October 21, 2003.

Address correspondence to: Aśok C. Antony, Indiana Cancer Research Institute, R4-266, 1044 West Walnut Street, Indianapolis, Indiana 46202-5121, USA. Phone: (317) 274-3589; Fax: (317) 274-0396; E-mail: aantony@iupui.edu.

Conflict of interest: The authors have declared that no conflict of interest exists.

Nonstandard abbreviations used: folate receptor (FR); glycosylphosphatidylinositol (GPI); high folate (-HF); low folate $(-L F)$; untranslated region (UTR); heterogeneous nuclear ribonucleoprotein E1 (hnRNP E1); pteroylglutamate (PteGlu); Dulbecco's PBS (D-PBS); chloramphenicol acetyltransferase (CAT); with a cis-element (+cis); lacking a cis-element (-cis). the FR by an endogenous membrane-associated metalloprotease can also yield a soluble hydrophilic species $(2,4)$. Although FRs are upregulated in folate deficiency and downregulated with repletion of folate (5-12), the molecular and biochemical link between folate deficiency and upregulation of FRs is not clear.

When a cervical carcinoma cell line $\left(\mathrm{HeLa}-\mathrm{IU}_{1}\right)$ that was stably propagated in $2.3 \mu \mathrm{M}$ folate (called HeLa$\mathrm{IU}_{1}-H F$ cells here, for "high folate") was adapted to growth in low physiological concentrations of folate (9 $\mathrm{nM}$ ) (called HeLa-IU ${ }_{1}-L F$ cells here, for "low folate"), the cells exhibited biochemical evidence of folate deficiency and FRs were markedly upregulated ninefold. However, the FR mRNA was disproportionately low (being increased by only twofold), suggesting that upregulation of FRs was a function of translational or posttranslational alterations in FR metabolism. Previously we demonstrated that the interaction of an 18-base ciselement in the $5^{\prime}$-untranslated region (5'-UTR) of FR- $\alpha$ isoform mRNA with a cytosolic trans-factor is critical for translational upregulation of FRs (13). More recently, we determined that the cytosolic FR mRNA-binding trans-factor is identical to the $43-\mathrm{kDa}$ heterogeneous nuclear ribonucleoprotein E1 (hnRNP E1) (14). HnRNP E1 is abundant in reticulocyte lysates (15), so the addition of recombinant hnRNP E1 to the in vitro translation mixture does not increase FR translation. However, anti-hnRNP E1 specifically inhibited trans- 
lation of FRs in vitro in a dose-dependent manner, and these effects could be reversed in a dose-dependent manner by either purified human placental trans-factor or hnRNP E1. These results confirmed the critical role of the interaction of cis-element and hnRNP E1 in the translation of FRs (14). The recent identification of a significant correlation between the expression of FRs and hnRNP E1 in the cervixes of normal women and those with cervical dysplasia and cervical cancer further supports the idea of a physiologic relationship (16). However, the obvious "missing link" to a more comprehensive understanding of the translational regulation of FRs (via involvement of these components) in folate deficiency was the precise trigger(s) for the interaction of FR mRNA cis-element and the hnRNP E1 resulting in upregulation of FRs.

This paper describes investigations into the functional role of this RNA-protein interaction in the regulation of FRs in HeLa-IU $\mathrm{I}_{1}$ cells within the context of folate homeostasis. We report that the marked upregulation of FRs observed in folate deficiency is mediated at the translational level by the metabolite homocysteine, which accumulates in folate deficiency and increases the interaction of the cis-element and hnRNP E1, which, in turn, results in increased biosynthesis of FRs. To our knowledge, this is the first time that a mechanistic linkage between substrate build-up from perturbed folate metabolism secondary to nutritional folate deficiency and the coordinated upregulation of a protein that is integrally involved in folate metabolism has been characterized at the translational level.

\section{Methods}

Materials. Nondialyzed and dialyzed fetal bovine serum, rabbit nonimmune serum, and other chemicals of the highest analytical grade were from Sigma Chemical Co. (St. Louis, Missouri, USA). The random hexanucleotide primer kit for all radiolabeled DNA probes (specific activity, $\sim 0.3 \mathrm{mCi} / \mu \mathrm{g} \mathrm{DNA}$ ) and QuickChange SiteDirected Mutagenesis Kit were from Stratagene (La Jolla, California, USA). The $\beta$-actin DNA was from Oncor (Gaithersburg, Maryland, USA). The plasmid pc32, a pUC 8 plasmid containing full-length human FR- $\alpha$ cDNA, was a gift from P.C. Elwood (National Cancer Institute, Medicine Branch, NIH, Bethesda, Maryland, USA) (17). All oligodeoxynucleotides were synthesized by Invitrogen (San Diego, California, USA). The primers for RT-PCR of FR cDNA were synthesized based on data provided (18). The $\left[3,5,7^{\prime}, 9^{\prime}-{ }^{3} \mathrm{H}\right]$ pteroylglutamate $\left(\left[3,5,7^{\prime}, 9^{\prime}-{ }^{3} \mathrm{H}\right]\right.$ PteGlu) potassium salt (specific activity, $\sim 50 \mathrm{Ci} / \mathrm{mmol}$ ); $\left[\alpha_{-}{ }^{32} \mathrm{P}\right] \mathrm{UTP}$ (specific activity, $>800$ $\mathrm{Ci} / \mathrm{mmol}$ ); and $\left[{ }^{35} \mathrm{~S}\right]$ cysteine (specific activity, $>1,000$ $\mathrm{Ci} / \mathrm{mmol}$ ) were from Amersham (Arlington Heights, Illinois, USA). IgGsorb, a $10 \%$ suspension of formalin-fixed Staphylococcus aureus cells bearing protein A, was from The Enzyme Center (Boston, Massachusetts, USA).

Cell culture. The addition of nondialyzed fetal bovine serum to a final concentration of $10 \%$ in folate-free minimum essential media (MEM) (Gibco-BRL,
Gaithersburg, Maryland, USA) led to a final extracellular concentration of 5-methyl-tetrahydrofolate of $9 \mathrm{nM}$; this media is referred to as MEM-LF. HeLa-IU ${ }_{1}$ cells (3) cultured at $37^{\circ} \mathrm{C}$ in $5 \% \mathrm{CO}_{2}$ and propagated in MEM containing $10 \%$ nondialyzed fetal bovine serum and 2.3 $\mu \mathrm{M}$ PteGlu (this media is referred to as MEM-HF) were designated HeLa-IU $\mathrm{I}_{1}-H F$ cells. HeLa-IU $1-L F$ cells were derived from HeLa-IU ${ }_{1}-H F$ cells that were abruptly transferred to MEM- $L F$ and stably adapted to growth in this media for over 6 months.

Analysis of metabolites related to folate metabolism in the growth media and in cells. The supernatant of HeLa-IU ${ }_{1-}^{-}$ $H F$ cells $\left(1.5 \times 10^{7}\right)$ propagated in low-folate media (MEM- $L F$ ) over several weeks was assayed for various metabolites as follows: Briefly, cells that were plated in 100- $\times 20-\mathrm{mm}$ dishes were fed twice a week with fresh MEM-LF. By the end of each week, growth media in contact with cells for 3 days was aspirated and frozen $\left(-80^{\circ} \mathrm{C}\right)$. The concentration of total homocysteine, methionine, total cysteine, and cystathionine was measured in these samples by gas chromatographymass spectrometry (19). S.P. Stabler was "blinded" to sample identity for all experiments by the use of coded samples (University of Colorado Health Sciences Center, Denver, Colorado, USA). In preliminary studies, we consistently failed to measure intracellular homocysteine concentrations in HeLa-IU $\mathrm{I}_{1}-H F$ and HeLa-IU $-L F$ cells after washing the cells with large volumes of buffer in order to separate homocysteine in the supernatant from cells. These results were consistent with the known propensity of homocysteine to rapidly move out of cells (20). Accordingly, efflux of homocysteine was minimized first by release of adherent cells with a rubber policeman (into the growth media used by the cells) and then by centrifugation of the suspension over silicone fluid to separate the media from cells. This approach has been validated as a very efficient method for the separation of cells from an aqueous phase (21, $22)$; thus, when $\left[{ }^{14} \mathrm{C}\right]$ inulin is added to a cell suspension that is centrifuged through a silicone matrix, less than $0.01 \%$ of $\left[{ }^{14} \mathrm{C}\right]$ inulin contaminates the cell pellet. The HeLa-IU ${ }_{1}-H F$ and HeLa-IU ${ }_{1}-L F$ cell pellets were then lysed and analyzed for homocysteine, methionine, cysteine, and cystathionine concentrations (19). Briefly, $7 \times 10^{5} \mathrm{HeLa}-\mathrm{IU}_{1}-\mathrm{HF}$ cells were seeded separately in 100- $\times 20-\mathrm{mm}$ Falcon tissue culture dishes (Becton Dickinson, Franklin Lakes, New Jersey, USA) in MEM-LF and were propagated for various times (up to 12 weeks) in this medium. By the end of each week, cell samples that had been uniformly fed with fresh MEM-LF 3 days prior to the day of harvest were analyzed for cell number, protein, and intracellular homocysteine. Accordingly, four dishes from each group were randomly selected and the number of cells was determined after trypsin digestion. The adherent cells from another four dishes from each group were released by being scraped with a rubber policeman and cells were resuspended in the same ("spent") growth medium. After being transferred to preweighed sterile 15 -ml polypropylene coni- 
cal Falcon tubes, cells were centrifuged at $1,000 \mathrm{~g}$ for 10 minutes. After aspiration of the supernatant, the pellet was digested in $25 \mu \mathrm{l}$ of $1 \mathrm{~N} \mathrm{NaOH}$ overnight at $37^{\circ} \mathrm{C}$ and the protein content was determined. Cells from another four dishes were also similarly scraped, resuspended in spent medium, and immediately applied to the tops of $15-\mathrm{ml}$ Falcon tubes containing $5 \mathrm{ml}$ of Versilube F50 silicone fluid (General Electric, Waterford, New York, USA). After centrifugation $(2,400 \mathrm{~g}$ for 10 minutes), the media was aspirated and tubes were immediately frozen on dry ice for 30 minutes to solidify the oil. The cell pellet was cut out from the bottom of the tube and resuspended in $500 \mu \mathrm{l}$ of fresh growth medium in an Eppendorf tube and subjected to four cycles of freezing and thawing (each cycle consisted of 5 minutes of freezing on dry ice followed by 20 minutes of thawing at $22^{\circ} \mathrm{C}$ ). The released intracellular contents were separated from other cell debris by centrifugation at $12,000 \mathrm{~g}$ for 10 minutes at $4^{\circ} \mathrm{C}$, and the supernatant was filtered through a $0.22-\mu \mathrm{m}$ filter and analyzed for homocysteine, methionine, cysteine, and cystathionine. The concentration of homocysteine, methionine, cysteine, and cystathionine in $500 \mu \mathrm{l}$ of fresh medium was also measured and this value was subtracted from the concentration of these thiols determined in spent medium and the cell pellet as a function of time (see Results). The data on homocysteine were expressed as micromolar and nanomoles per milligram of protein. These experiments were repeated four different times and the data were expressed as the mean $\pm \mathrm{SD}$. In other experiments, the extent of intracellular accumulation of homocysteine following exposure of $\mathrm{HeLa}-\mathrm{IU}_{1}$ $H F$ cells to $500 \mu \mathrm{M}$ and $1000 \mu \mathrm{M}$ of homocysteine was also determined after rapid separation over silicone. For the experiments that used pharmacological concentrations of homocysteine, an additional control was included in which each concentration of homocysteine in vehicle was also applied to the silicone column (in the absence of cells) and the amount of homocysteine recovered in the "cell pellet" fraction was measured. Because this value at each concentration represented nonspecific passage of homocysteine through silicone, it was subtracted from the values from studies using cells.

Radiolabeled folic acid (PteGlu) binding studies. Binding of radiolabeled $\left[{ }^{3} \mathrm{H}\right]$ PteGlu to intact cells on each week during long-term culture (Figure 1) was carried out as described (23), with the following modifications. Cells $\left(2 \times 10^{6}\right)$ were cultured in T-75 flasks to $80 \%$ confluence, and endogenous (FR-bound) folate was removed by washing cells using the following buffers in sequence (at $4^{\circ} \mathrm{C}$ ): $10 \mathrm{ml}$ Dulbecco's PBS (D-PBS), four washes; $10 \mathrm{ml}$ $0.05 \mathrm{M}$ sodium acetate-acetic acid ( $\mathrm{pH} 4.5)$ containing $0.15 \mathrm{M} \mathrm{NaCl}$ (30 seconds per wash), two washes; $0.01 \mathrm{M}$ sodium phosphate containing $0.15 \mathrm{M} \mathrm{NaCl}$ ( $\mathrm{pH} 7.4$ ), one wash. After cells were released by being incubated with isotonic trypsin-EDTA (Gibco BRL) for 5 minutes at $37^{\circ} \mathrm{C}$, they were washed twice in $10 \mathrm{ml} \mathrm{D}$-PBS.

Binding of radioligand to FRs on intact cells was determined at $4^{\circ} \mathrm{C}$ in $15-\mathrm{ml}$ sterile tubes by incubation of $1 \times 10^{6}$ cells with varying concentrations of $\left[{ }^{3} \mathrm{H}\right]$ PteGlu $(0.0625-128 \mathrm{nM})$ in the absence or presence of a 1,000-fold excess of unlabeled folic acid for 1 hour (equilibrium binding time at $4^{\circ} \mathrm{C}$ ) in a final volume of 1 $\mathrm{ml}$ D-PBS. The cells were washed four times with $10 \mathrm{ml}$ D-PBS. After the cell pellet containing bound $\left[{ }^{3} \mathrm{H}\right] \mathrm{PteGlu}$ was digested in $50 \mu \mathrm{l}$ of $1 \mathrm{~N} \mathrm{NaOH}$ overnight, the sample was analyzed by liquid scintillation spectrometry. Specific $\left[{ }^{3} \mathrm{H}\right]$ PteGlu binding was determined by subtracting the value of nonspecific $\left[{ }^{3} \mathrm{H}\right]$ PteGlu binding (obtained in duplicate samples containing 1,000-fold excess of unlabeled folic acid) from total $\left[{ }^{3} \mathrm{H}\right]$ PteGlu binding (determined from samples containing radiolabeled $\left[{ }^{3} \mathrm{H}\right]$ PteGlu alone). Nonspecific [ $\left.{ }^{3} \mathrm{H}\right]$ PteGlu binding was less than $10 \%$ of total binding in all experiments. The total number of FRs per cell by the end of each week in long-term culture in low-folate medium (Figure 1) was calculated based on Scatchard analysis of the data. Each data point represents four independent experiments.

Western blot analysis. Cells were lysed overnight in a buffer containing $2 \%$ SDS, $20 \mathrm{mM}$ EDTA, $1 \mu \mathrm{g} / \mathrm{ml}$ aprotinin, and $1 \mathrm{mM}$ PMSF (all from Sigma). Fifteen micrograms of total protein was analyzed by $4-20 \%$ SDSPAGE followed by Western blotting. The proteins transferred to PVDF membranes were first incubated with rabbit polyclonal anti-human placental FR antiserum (dilution, $1: 1500$ ) overnight at $4^{\circ} \mathrm{C}$, followed by incubation for 1 hour with a 1:15,000 dilution of peroxidase-coupled goat anti-rabbit antibody. Antibodyprotein complexes were then detected using the ECL detection kit (Amersham) followed by autoradiography. A densitometric comparison of the intensity of the FR signal from cells at the end of each week in long-term culture (Figure 1) with that value of the FR signal obtained at time zero allowed for an estimate of the fold increase in FR expression in cells as a function of time.

Morphometric and morphological studies. HeLa-IU $\mathrm{U}_{1}-\mathrm{HF}$ and HeLa-IU $\mathrm{I}_{1}-L F$ cells at $80 \%$ confluency were washed with D-PBS and harvested after exposure to isotonic trypsin-EDTA. Cells $\left(1 \times 10^{4}\right)$ were then transferred to glass slides, and total cell and nuclear diameters were quantitatively determined (24).

RT-PCR. Total cellular RNA from HeLa-IU $\mathrm{H}_{1}-\mathrm{HF}$ and HeLa-IU ${ }_{1}-L F$ cells was isolated, poly $(A)^{+}$RNA was purified (Invitrogen), and reverse transcription was carried out (Boehringer Mannheim, Indianapolis, Indiana, USA). The cDNA fragments of different FR isoforms were amplified (Perkin-Elmer, Branchburg, New Jersey, USA) using similar amplification conditions and primers specific for the FR- $\alpha$, FR- $\beta$, and FR- $\gamma$ isoforms (18), except that one specific primer for FR- $\alpha$ was $5^{\prime}$ GGAGgCTCAGACAAGGATTG- $3^{\prime}$. The PCR products were separated by electrophoresis through $2 \%$ agarose gels, stained with ethidium bromide, and visualized by UV illumination. After Southern transfer, hybridization was accomplished with ${ }^{32}$ P-labeled FR cDNA followed by autoradiography (25).

FR $m R N A$ expression and stability. FR mRNA expression was determined in HeLa-IU $\mathrm{I}_{1}-H F$ and HeLa-IU $1-L F$ cells, and HeLa-IU ${ }_{1}-H F$ cells cultured in low-folate medium 


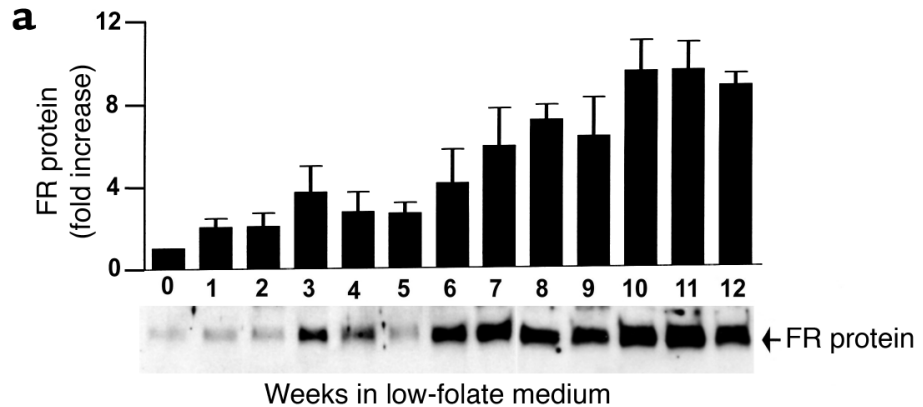

b
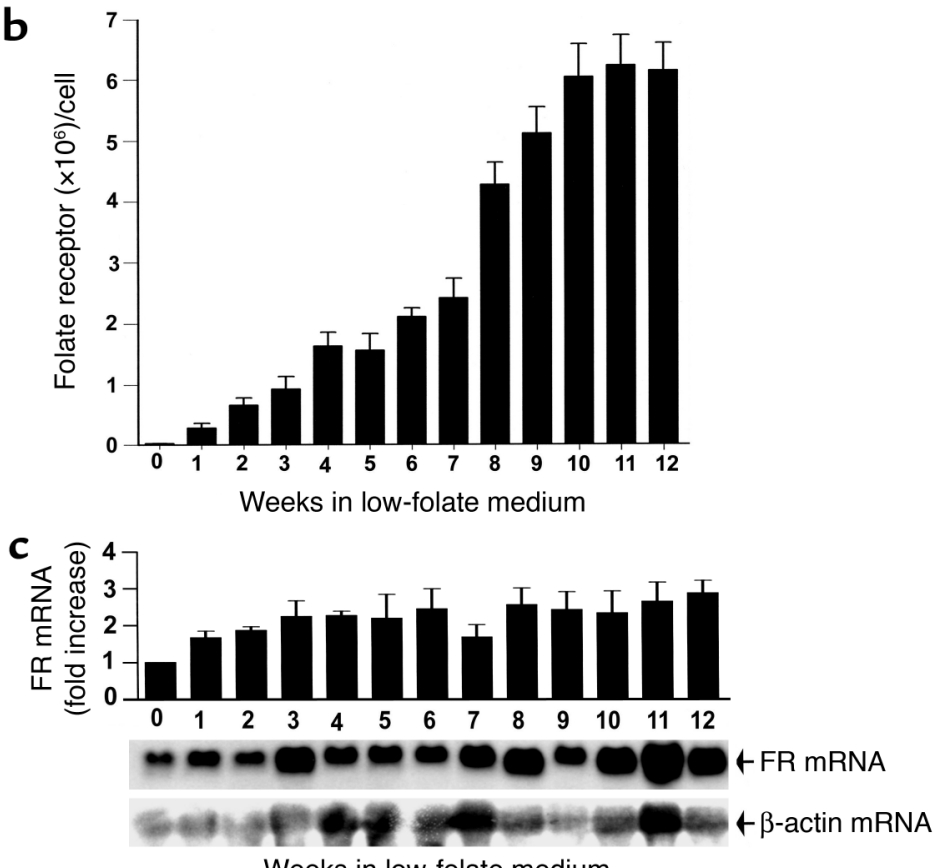

Weeks in low-folate medium

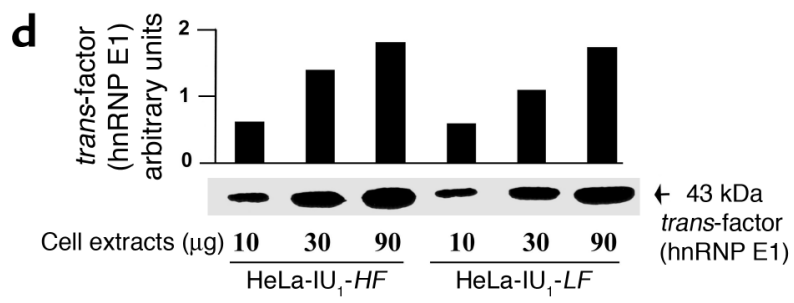

for up to 12-weeks as described (25). Briefly, RNA was extracted from cells cultured in 10-cm dishes, and 20 $\mu \mathrm{g}$ total RNA per lane was separated by electrophoresis through $1.5 \%$ agarose/2.2 $\mathrm{M}$ formaldehyde gels and transferred to nylon membranes (Roche Diagnostics Corp., Indianapolis, Indiana, USA). The probes were labeled with [digoxigenin]dUTP using the PCR DIG probe synthesis kit (Roche Diagnostics Corp.) and membranes were developed using the DIG luminescent detection kit (Roche Diagnostics Corp.) and autoradiography. The relative expression of FR mRNA at the end of each week (see Figure 1) was determined as follows: The densitometric-scanning data of the FR mRNA signal for each sample was first normalized to the corresponding $\beta$-actin mRNA signal of that sample using an IS-1000 digital imaging system (Alpha Innotech, Torrance, California, USA). The fold increase

\section{Figure 1}

Analysis of FR protein, FR mRNA, and hnRNP E1 in HeLa-IU ${ }_{1}-H F$ cells propagated in low-folate media over 12 weeks. (a) Western blot analysis of the expression of FR protein as a function of time after shift of HeLa$\mathrm{IU}_{1}-\mathrm{HF}$ cells to low-folate media. Each data point (fold increase of FR protein as a function of time) represents the mean \pm SD of four independent evaluations. The Western blot data shown represent one of the four studies. (b) Determination of the cell surface receptor number by $\left[{ }^{3} \mathrm{H}\right]$ folate-binding to intact cells and Scatchard analysis as a function of time after shifting of HeLa-IU ${ }_{1}-H F$ cells to low-folate media. Each data point represents the mean \pm SD of four independent evaluations. (c) Northern blot analysis of FR mRNA relative to $\beta$-actin mRNA expression as a function of time after shifting of $\mathrm{HeLa}-\mathrm{IU}_{1}-\mathrm{HF}$ cells to low-folate media. Signals from Northern blot analysis of $10 \mu \mathrm{g}$ of total cellular RNA from cells for the indicated times were quantitated by densitometry. The quantity of the FR mRNA was normalized to that of $\beta$-actin mRNA. Each data point (fold increase of FR mRNA as a function of time) represents the mean \pm SD of four independent evaluations. The Northern blot data shown represent one of the four studies. (d) Northwestern gel analysis of the FR mRNA-binding hnRNP E1 from HeLa-IU $-H F$ cells and HeLa-IU $U_{1}-L F$ cells probed with FR- $\alpha$ mRNA cis-element (3). The FR- $\alpha$ RNA sequence $5^{\prime}$-CUCCAUUCCCACUCCCUG-3' was labeled by in vitro transcription. Densitometric analysis of the signals is shown in the panel. in FR mRNA expression in cells as a function of time was then determined by dividing the individual value of FR mRNA expression for each week by the value obtained at week zero (Figure 1).

For the determination of FR mRNA stability, $1 \times 10^{6}$

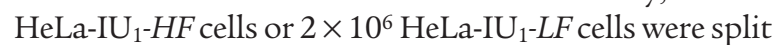
into $100-\times 20-\mathrm{mm}$ dishes. Three days later, cells were exposed to $5 \mu \mathrm{g} / \mathrm{ml}$ of actinomycin $\mathrm{D}$ for $2,4,6$, and 8 hours. Total cellular RNA $(10 \mu \mathrm{g})$ from unexposed and exposed cells was then analyzed on Northern blots (3).

Nuclear run-on assay. Five micrograms of denatured FR- $\alpha$ cDNA and $\beta$-actin DNA were hybridized to filters blotted with equal amounts of $[\alpha-32$ P]UTP nuclear RNA from $2 \times 10^{7} \mathrm{HeLa}^{-\mathrm{IU}_{1}-H F \text { or HeLa-IU }} \mathrm{H}_{1}-L F$ cells (26).

Biosynthetic radiolabeling of bydrophobic FR. For biosynthetic studies, dialyzed fetal bovine serum $\left(1,000-\mathrm{M}_{\mathrm{r}}\right.$ cut-off filter) was used whenever cysteine-free MEM or 
MEM containing $\left[{ }^{35} \mathrm{~S}\right]$ cysteine was used. However, during chase periods, regular (cysteine-replete) media containing nondialyzed fetal bovine serum was utilized.

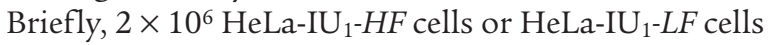
were cultured in $100-\times 20-\mathrm{mm}$ dishes to about $80 \%$ confluence. The monolayers were rinsed three times with D-PBS and "starved" for 18 hours in $8 \mathrm{ml}$ cysteinefree MEM- $H F$ or MEM- $L F$, respectively. For determination of the synthetic rate of FRs, $6 \times 10^{6}$ to $8 \times 10^{6}$ cells were pulsed with $\left[{ }^{35} \mathrm{~S}\right]$ cysteine $(250 \mu \mathrm{Ci})$ in $4 \mathrm{ml}$ of cysteine-free MEM- $H F$ or MEM- $L F$, respectively, for various times indicated (up to 4 hours) at $37^{\circ} \mathrm{C}$ (see Figure 2). After being rinsed twice with D-PBS, the cells were harvested with a plastic cell scraper into $10 \mathrm{ml}$ D-PBS containing $20 \mathrm{mM}$ EDTA, $100 \mu \mathrm{g} / \mathrm{ml}$ phenylmethylsulfonyl fluoride, and $1 \mu \mathrm{g} / \mathrm{ml}$ aprotinin (buffer $\mathrm{A}$ ) and were centrifuged at $500 \mathrm{~g}$ for 5 minutes. Cell pellets were then solubilized in $1 \mathrm{ml}$ of buffer A containing $1.5 \%$ Triton X-114 at $4^{\circ} \mathrm{C}$ for 24 hours. After centrifugation at $13,600 \mathrm{~g}$ for 15 minutes at $4^{\circ} \mathrm{C}$, the supernatant was transferred to a fresh tube and an aliquot was removed for the determination of protein concentration. After four cycles of temperature-induced phase-separation (27) in buffer A for the removal of free $\left.{ }^{[35} \mathrm{S}\right]$ cysteine, the Triton X-114 micellar phase was reconstituted to $1 \mathrm{ml}$ with buffer $\mathrm{A}$. The samples containing hydrophobic $\left[{ }^{35} \mathrm{~S}\right] \mathrm{FR}$ were subsequently subjected to immunoprecipitation with anti-placental FR antiserum (see below). To determine the degradation rate of FR, cysteine-depleted cells were pulsed with $\left[{ }^{35} \mathrm{~S}\right]$ cysteine $(400 \mu \mathrm{Ci})$ in $4 \mathrm{ml}$ of cysteine-free MEM-HF or MEM- $L F$ for 8 hours at $37^{\circ} \mathrm{C}$ followed by chase with MEM- $H F$ or MEM-LF, respectively. At various later times, hydrophobic $\left[{ }^{35} \mathrm{~S}\right] \mathrm{FR}$ was quantitated by specific immunoprecipitation (described below).

For biosynthetic labeling of FR of HeLa-IU $\mathrm{H}_{1}-H F$ cells with $\left[{ }^{3} \mathrm{H}\right]$ leucine, cells were starved overnight with leucine-free MEM-HF before being pulsed with $\left[{ }^{3} \mathrm{H}\right]$ leucine for $0.5,1$, and 2 hours in the absence and presence of $0.5 \mathrm{mM}$ or $1 \mathrm{mM}$ dl-homocysteine.

Validation that the procedure for immunoprecipitation of de novo-synthesized FR by anti-FR antiserum includes incompletely glycosylated forms. We conducted experiments to validate the fact that our protocol using anti-placental FR antiserum and IgGsorb immunoprecipitated all full-length de novo synthesized $\left[{ }^{35} \mathrm{~S}\right] \mathrm{FR}$ polypeptides in HeLa-IU ${ }_{1}$ cells. First, HeLa-IU $1-L F$ cells were pulsed for up to four hours with $\left[{ }^{35} \mathrm{~S}\right]$ cysteine followed by immunoprecipitation of $20 \mu \mathrm{g}$ of total cellular proteins at various times (from 30 minutes to four hours) with

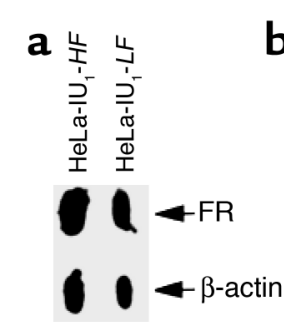

f

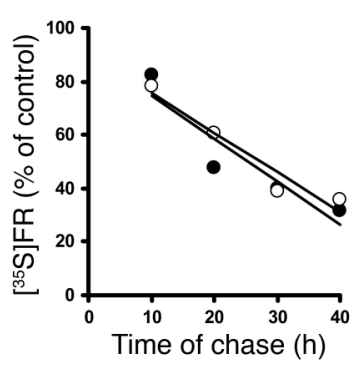

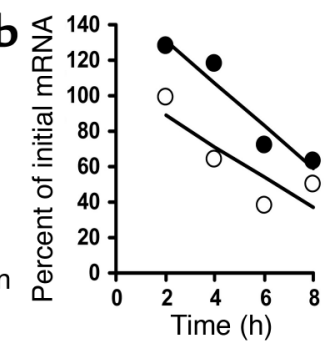

$\mathrm{g}$

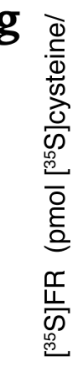

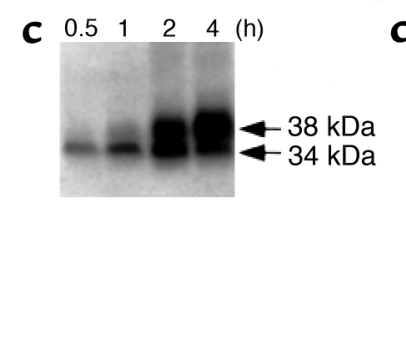

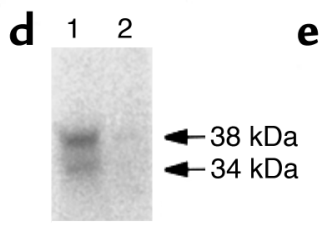

e 12

h

(h) $\begin{array}{llllllll}0.5 & 1 & 2 & 4 & 0.5 & 1 & 2 & 4\end{array}$

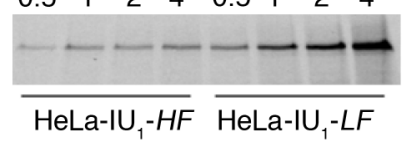

\section{Figure 2}

Determination of the locus of upregulation of FR in HeLa-IU $1-L F$ cells. (a) FR gene transcription. Nuclei $\left(5 \times 10^{7}\right)$ from HeLa-IU $1-H F$ and HeLa$I U_{1}-L F$ cells were used in nuclear run-on transcription assays. Equal amounts of $\left[\alpha-{ }^{32} \mathrm{P}\right] \mathrm{UTP}$ nuclear RNA were hybridized to filters blotted with $5 \mu \mathrm{g}$ of denatured plasmid DNA containing human $\beta$-actin cDNA or human FR cDNA, followed by autoradiography. (b) Analysis of FR mRNA stability in HeLa-IU $U_{1}-H F$ (open circles) and HeLa-IU $-L F$ (filled circles) cells exposed to actinomycin D for the indicated times followed by Northern blot analysis. The curve-fitting analysis of FR mRNA was determined by linear regression. (c-e) Validation that the procedure for immunoprecipitation of the de novo-synthesized FR with anti-FR antiserum includes incompletely glycosylated forms (see Methods for details). (f) Analysis of the rates of FR protein degradation of either six million HeLa-IU $U_{1}-H F$ cells (open circles) or HeLa-IU $1_{1}-L F$ cells (filled circles) that were pulsed with $\left[{ }^{35} \mathrm{~S}\right]$ cysteine, chased with high-folate media (open circles) or low-folate media (filled circles) for the various times indicated, and immunoprecipitated $\left.{ }^{35} \mathrm{~S}\right] \mathrm{FR}$ was determined. The curve-fitting analyses in protein half-life studies were determined by linear regression. (g) Analysis of the rates of FR protein synthesis of HeLa-IU ${ }_{1}-H F$ cells (filled diamonds) and HeLa-IU 1 -LF cells (filled squares). $6 \times 10^{6}$ cells were pulsed with $\left[{ }^{35} \mathrm{~S}\right]$ cysteine for the indicated time, and immunoprecipitated $\left[{ }^{35} \mathrm{~S}\right] \mathrm{FR}$ was determined by liquid scintillation counting. There was less than $15 \%$ variation from the mean for each data point of triplicate samples. The data are representative of a typical experiment that was repeated on three different occasions. (h) Comparison of the intensity of immunoprecipitated $\left[{ }^{35} \mathrm{~S}\right] \mathrm{FR}$ signals from HeLa-IU $\mathrm{H}_{1} \mathrm{HF}$ and HeLa-IU ${ }_{1}-L F$ cells after $10 \%$ SDS-PAGE, Western blotting, and autoradiography. 
anti-placental FR antiserum followed by $12.5 \%$ SDSPAGE and fluorography of the gel (Figure 2c). Next, total cellular $\left[{ }^{35} \mathrm{~S}\right]$ cysteine-labeled proteins from HeLa$\mathrm{IU}_{1}-L F$ cells $(20 \mu \mathrm{g})$ were incubated with $20 \mu \mathrm{l}$ anti-placental FR antiserum and immunoprecipitated with IgGsorb (Figure 2d, lane 1); the remaining supernatant was also subjected to the same (anti-placental FR antiserum plus IgGsorb) treatment and analyzed (Figure $2 \mathrm{~d}$, lane 2). Finally, HeLa-IU $U_{1}-L F$ cells were starved for one hour with cysteine-free MEM- $L F$ without (Figure $2 \mathrm{e}$, lane 1) or with (Figure 2e, lane 2) $1 \mu \mathrm{M}$ monensin and pulsed for two hours with $\left[{ }^{35} \mathrm{~S}\right]$ cysteine in the absence or presence of monensin, respectively, before immunoprecipitation of $\left.{ }^{35} \mathrm{~S}\right] \mathrm{FR}$.

Specific immunoprecipitation of $\left[{ }^{35} S\right] F R$ and UV crosslinked RNA-protein complexes. Ten microliters of nonimmune serum was incubated with solubilized $\left[{ }^{35} \mathrm{~S}\right] \mathrm{FR}$ or UV-cross-linked RNA-protein complexes at $4^{\circ} \mathrm{C}$ for 2 hours on a shaking platform. IgGsorb $(200 \mu \mathrm{l})$ was then added and samples were incubated for 2 hours, followed by centrifugation at $13,600 \mathrm{~g}$ for 5 minutes at $4^{\circ} \mathrm{C}$ to remove nonspecifically adsorbed proteins. The supernatant was aspirated and divided into six aliquots of $20 \mu \mathrm{g}$ protein each. After the addition of $20 \mu \mathrm{l}$ of rabbit anti-human placental FR antiserum (28) or anti-hnRNP E1 antiserum (14) or nonimmune serum (to three aliquots each), the final volume of each sample was brought up to $500 \mu \mathrm{l}$ with D-PBS containing $1 \%$ Triton X-100 and $20 \mathrm{mM}$ EDTA. Following incubation at $4^{\circ} \mathrm{C}$ for 18 hours, $200 \mu \mathrm{l}$ of IgGsorb was added. After incubation for 2 hours and centrifugation at $13,600 \mathrm{~g}$ for 5 minutes at $4^{\circ} \mathrm{C}$, the pellets $(20 \mu \mathrm{l}$ each) were washed with $1 \mathrm{ml}$ of buffer $A$ four times and were resuspended in $0.48 \mathrm{ml}$ D-PBS. An aliquot $(50 \mu \mathrm{l})$ was mixed with $10 \mathrm{ml}$ of counting cocktail and analyzed for radioactivity in a $\beta$-scintillation counter. The data obtained with nonimmune serum was subtracted from that obtained with anti-placental FR antiserum or anti-hnRNP E1 antiserum to derive values for specific $\left[{ }^{35} \mathrm{~S}\right]$ cysteine incorporated into FRs or specific $\left[{ }^{32} \mathrm{P}\right] c i s-$ element RNA-hnRNP E1 complexes immunoprecipitated. The remaining samples (from triplicates) were then combined, concentrated to $100 \mu \mathrm{l}$, and analyzed by SDS-PAGE and autoradiography.

Analysis of hydrophilic FR released into the growth media. After HeLa-IU ${ }_{1}-H F$ and HeLa-IU $U_{1}-L F$ cells were pulsed for 8 hours with $\left[{ }^{35} \mathrm{~S}\right]$ cysteine, the $\left[{ }^{35} \mathrm{~S}\right]$ hydrophilic FRs $\left({ }^{35}\right.$ S-labeled hydrophilic FRs) released into the media were concentrated by ultrafiltration $\left(\mathrm{M}_{r}\right.$ cutoff $=$ $10,000)$ using Diaflo filters (Amicon, Danvers, Massachusetts, USA) (28), and quantitated by immunoprecipitation with anti-placental FR antiserum.

Northwestern blot analysis and gel-shift assays. Possible differences in the interaction of the 18-base cis-element in the 5'-UTR of FR mRNA and cytosolic 43-kDa hnRNP E1 from HeLa-IU $U_{1}$ cells propagated under various extracellular folate concentrations were assessed by Northwestern blot analysis (13). Gel-shift assays were used to determine the effect of homocysteine and other agents in increasing the interaction of the radiolabeled 18-base FR mRNA cis-element or its mutants with the specific hnRNP E1 from cytosolic extracts of HeLa-IU $1-H F$ cells (S-100 fraction) that were dialyzed in buffer without dithiothreitol (DTT) (13). Briefly, $\left[{ }^{32} \mathrm{P}\right]$ cis-element $(10,000$ $\mathrm{cpm}$ ) was allowed to react for 30 minutes at $22^{\circ} \mathrm{C}$ with 20 $\mu \mathrm{g}$ of dialyzed S-100 fraction from HeLa-IU $\mathrm{U}_{1}-H F$ cells with various concentrations of L-methionine, L-cysteine, DL-homocysteine thiolactone, DL-homocysteine, D-homocystine, L-homocystine, $\beta$-mercaptoethanol, glutathione, or DTT. After the addition of RNase T1 and heparin and incubation for 20 minutes, RNA-protein complexes were separated by electrophoresis (6\% native PAGE; acrylamide:bis-acrylamide, 60:1) followed by autoradiography (13). In other experiments, the effect of folic acid or 5methyl-tetrahydrofolate in modulating the RNA-protein interaction in the absence or presence of homocysteine was also assessed using dialyzed S-100 fractions. Briefly, S-100 fractions from HeLa-IU $\mathrm{I}_{1}-\mathrm{HF}$ cells were extensively dialyzed in DTT-free buffer. Next, $20 \mu \mathrm{g}$ of the dialyzed sample, which was supplemented with $1 \mathrm{mM}$ dl-homocysteine, was allowed to react for 30 minutes at $22^{\circ} \mathrm{C}$ with $\left.{ }^{32} \mathrm{P}\right]$ cis-element $(10,000 \mathrm{cpm})$, and increasing concentrations $(10 \mathrm{nM}$ to $100 \mu \mathrm{M})$ of either folic acid or 5-methyltetrahydrofolate was added to the RNA-protein mixture; freshly prepared 5-methyltetrahydrofolate was added within 15 minutes of the opening of a new vial. After the addition of RNaseT1 and heparin and incubation for another 20 minutes, the intensities of the RNA-protein complex signals were determined (13).

Plasmid construction. The plasmid containing chloramphenicol acetyltransferase (CAT) and the cis-element [pCAT $(+c i s)$ ] was constructed by replacing a 223-bp intron from the PCAT3 control vector (Promega, Madison, Wisconsin, USA) with a 200-bp fragment of the $5^{\prime}$ UTR of FR cDNA containing the 18-base cis-element at the HindIII site. The pCAT (-cis) plasmid, a control plasmid with deletion of the 18-base cis-element, was prepared using site-directed mutagenesis in which the primers $5^{\prime}$-GCTCCACTCCTGGGCCTGTCTCCTAG- ${ }^{\prime}$ and 5'-CTAGGAGACAGGCCCAGGAGTGGAGC-3' were used. The plasmids $\mathrm{pN}, \mathrm{pC} 1, \mathrm{pC} 2$, and $\mathrm{pC} 12$ were constructed by subcloning the four pairs of oligodeoxynucleotides (shown below) into the PSPT18 vector that was linearized with EcoRI and HindIII to generate the 18-base cis-element RNA and its mutants. The orientation and point mutations were confirmed in all plasmids sequencing: pN: 5'-p-AATTCGCTCCATT CCCACTCCCTGA-3' 3'-GCGAGGTAAGGGTGAGGGACTTCGA-p-5' pC1: $5^{\prime}$-p-AATTCGCTACATT CCCACTCCCTGA-3' $3^{\prime}$-GCGATGTAAGGGTGAGGGACTTCGA-p-5'; pC2: 5'-p-AATTCGCTCCATT CCCACTACCTGA-3'; 3'-GCGAGGTAAGGGTGATGGACTTCGA-p-5'; pC12: 5'-p-AATTCGCTACATTCCC ACTACCTGA$3^{\prime} ; 3^{\prime}$-GCGATGTAAGGGTGATGGACTTCGA-p-5'.

Transfection of HeLa-IU $U_{1}-H F$ and HeLa-IU $-L F$ cells with CAT reporter constructs driven by a 5'-UTR of FR $m R N A$ in which the cis-element is retained [PCAT (+cis)] or deleted $[p C A T(-c i s)]$. The pSV- $\beta$-galactosidase (Promega) was cotransfected with either pCAT $(+c i s)$ or pCAT $(-c i s)$, 
which permitted assay for both $\beta$-galactosidase activity (by a $\beta$-Gal reporter gene assay using a chemiluminescence assay) and CAT ELISA (Roche Diagnostics Corp.). The extent of $\beta$-galactosidase activity served as an internal control for transfection efficiency of PCAT (+cis) or pCAT (-cis) into HeLa-IU ${ }_{1}-H F$ and HeLa-IU $\mathrm{I}_{1}-L F$ cells. The results of negative control cell extracts, prepared from nontransfected cells and assayed for both $\beta$-galactosidase and CAT, were routinely subtracted from the results obtained from transfected cell extracts. Briefly, cells were plated 1 day before being transfected in culture media (MEM- $H F$ or MEM- $L F$ for HeLa-IU $1-H F$ or HeLa-IU $-L F$ cells, respectively) at a density of $2.5 \times 10^{5}$ cells/well using six-well plates to achieve $50-80 \%$ confluency on the day of transfection. The FuGENE-6 (Roche Diagnostics Corp.) transfection reagent was used with each plasmid DNA [either pCAT $(+c i s)$ or pCAT $(-c i s)$ and pSV- $\beta$-galactosidase] at a ratio of 3:2 (3 $\mu \mathrm{l}$ FuGene-6, $2 \mu \mathrm{g}$ DNA of each plasmid, and $97 \mu \mathrm{l}$ serum-free media) per well, and transfection was carried out according to the manufacturer's instructions. Determination of the identity of the protein within RNA-protein complexes induced by intracellular homocysteine in HeLa$I U_{1}-L F$ cells by gel supershift assays. Cytosolic protein extracts (S-100 fraction) from HeLa-IU ${ }_{1}$ cells were prepared as described below. Briefly, HeLa-IU ${ }_{1}-H F$ and HeLa-IU ${ }_{1}-L F$ cells were cultured in MEM- $H F$ and MEM$L F$ media, respectively, for 3 days to approximately $80 \%$ confluence. After cells were harvested with a rubber policeman, the cell suspensions were centrifuged over Versilube F50 silicone fluid to separate media and cells as described above. Cells were incubated in two packed cell volumes of buffer A (10 mM HEPES, pH 7.9, containing $1.5 \mathrm{mM} \mathrm{MgCl}_{2}$ and $10 \mathrm{mM} \mathrm{KCl}$ ) for 10 minutes at $4{ }^{\circ} \mathrm{C}$, and then were lysed by 30 strokes of a Kontes allglass Dounce homogenizer (B-type pestle). After confirmation of cell lysis and recentrifugation (at $800 \mathrm{~g}$ for 10 minutes at $4^{\circ} \mathrm{C}$ ), the supernatant was mixed with 0.11 volumes of buffer B (300 mM HEPES, pH 7.9, containing $30 \mathrm{mM} \mathrm{MgCl}_{2}$ and $1.4 \mathrm{M} \mathrm{KCl}$ ), and centrifuged for 60 minutes at 100,000 $\mathrm{g}$ (in a Beckman Type SW 55.Ti rotor). The protein concentration of the supernatant was measured by bicinchonic acid assay (Pierce, Rockford, Illinois, USA) and $500-\mu \mathrm{l}$ aliquots were frozen at $-80^{\circ} \mathrm{C}$ (S-100 fraction). RNA-protein binding reactions were carried out with $800 \mu \mathrm{g}$ cytosolic extracts from HeLa$\mathrm{IU}_{1}-H F$ or HeLa-IU $-L F$ cells and $1 \times 10^{6} \mathrm{cpm}$ of $\left[{ }^{32} \mathrm{P}\right]$ ciselement in $10 \mathrm{mM}$ HEPES, $\mathrm{pH} 7.6$, containing $3 \mathrm{mM}$ $\mathrm{MgCl}_{2}, 40 \mathrm{mM} \mathrm{KCl}, 5 \%$ glycerol, and $600 \mathrm{ng} / \mu \mathrm{l}$ yeast transfer RNA in a final volume of $300 \mu \mathrm{l}$. After samples were incubated at room temperature for $30 \mathrm{~min}, 500$ units of RNase T1 and $20 \mu \mathrm{l}$ of heparin solution (100 $\mathrm{mg} / \mathrm{ml}$ ) were added and incubation was continued for another 30 minutes. Aliquots of $15 \mu \mathrm{l}$ were then incubated with anti-hnRNP E1 antiserum or nonimmune serum overnight followed by a gel-shift assay (14) to demonstrate a supershift with antiserum and the identity of the protein within the cis-element and trans-factor complex. The remainder of the RNA-protein complexes were transferred to 24-well plates and irradiated from a distance of $1 \mathrm{~cm}$ by a UV lamp (300 nm, 70,000 $\mu \mathrm{W} / \mathrm{cm}^{2}$; Fotodyne Inc., New Berlin, Wisconsin, USA) for 1 hour at $4^{\circ} \mathrm{C}$ followed by specific immunoprecipitation of UV cross-linked RNA-protein complexes.

Statistical analysis. The curve-fitting analyses were determined by linear regression (Microsoft Excel). Unless otherwise stated, all experiments were carried out on three different occasions with less than $15 \%$ variation from the mean for each data point.

\section{Results}

Characterization of the upregulation of FRs in folate-deficient cells. Although HeLa-IU $1-L F$ cells (stably propagated in low-folate media) were slightly larger than HeLa-IU $\mathrm{I}_{1}-\mathrm{HF}$ cells (stably propagated in folate-replete media), there was no evidence for megaloblastosis by morphologic and morphometric criteria (not shown). However, although the nuclear:cytoplasmic ratio was not increased (24), these cells continued to proliferate, albeit at a slower rate, with a change in doubling time from 22 hours (basal in HeLa-IU $1-H F$ cells) to 31 hours in HeLa$\mathrm{IU}_{1}-L F$ cells (Table 1$)$. In addition, the basal concentration of total homocysteine in the media, a surrogate marker for intracellular folate deficiency when elevated (29), was $108 \mu \mathrm{M}$ for HeLa-IU $U_{1}-L F$ cells and $14 \mu \mathrm{M}$ for HeLa-IU ${ }_{1}-H F$ cells (humans with clinical folate deficiency also have increases in serum total homocysteine; refs. 1, 29, 30). This 7.7-fold increase of total homocysteine in the media indicated that HeLa-IU $\mathrm{U}_{1}-L F$ cells were indeed folate deficient. Thus, morphological evaluation of HeLa-IU $-L F$ cells was insufficiently sensitive to diagnose mild folate deficiency, as observed clinically in humans, in whom elevations of total homocysteine precedes a reduction of serum folate below normal levels

\section{Table 1}

Summary of changes in several parameters of FR metabolism in HeLa-IU 1 cells under basal conditions in high-folate media (HeLa$\left.\mathrm{IU}_{1}-H F\right)$ and following stable adaptation to low extracellular folate concentration (HeLa-IU $1-L F)$

\begin{tabular}{|c|c|c|}
\hline Parameter & HeLa-IU $1-H F$ & HeLa-IU $1-L F$ \\
\hline Doubling time (h) & 22 & 31 \\
\hline Cell diameter $(\mu \mathrm{m})$ & $18 \pm 4$ & $28 \pm 8$ \\
\hline Nuclear diameter $(\mu \mathrm{m})$ & $12 \pm 3$ & $20 \pm 6$ \\
\hline Cell surface area $\left(\mu \mathrm{m}^{2}\right)$ & 1,017 & 2,497 \\
\hline Nuclear:cytoplasmic ratio ${ }^{A}$ & basal & unchanged \\
\hline Media total homocysteine $(\mu \mathrm{M})$ & 14 & 108 \\
\hline Cell surface FRs (receptors/cell) & $2.2 \times 10^{4}$ & $6.0 \times 10^{6}$ \\
\hline Cell surface FRs (molecules $/ \mu \mathrm{m}^{2}$ ) & 22 & 2,412 \\
\hline FR mRNA ${ }^{A}$ & basal & increased 2-fold \\
\hline Transcription rate $\mathrm{A}^{\mathrm{A}}$ & basal & increase 1.4 -fold \\
\hline FR mRNA stability ${ }^{A}$ & basal & unchanged \\
\hline Rate of FR synthesis $(\mathrm{pmol} / \mathrm{mg} / \mathrm{h})^{\mathrm{B}}$ & 0.0053 & 0.087 \\
\hline Rate of FR degradation $\left(t_{1 / 2}\right)$ & 24 hours & 26 hours \\
\hline $\begin{array}{l}\text { Hydrophilic FR released into } \\
\text { the media }(\mathrm{pmol} / \mathrm{mg})^{B}\end{array}$ & 0.013 & 0.035 \\
\hline
\end{tabular}

${ }^{A}$ Data are compared with basal conditions of culture (of HeLa-IU $\mathrm{U}_{1}-\mathrm{HF}$ cells). ${ }^{\mathrm{B}} \mathrm{pmol}$ indicates picomoles of cysteine incorporated into FR. 
and morphological manifestations (1, 30-32). Western blot analysis of the extent of total membrane-associated FR expression (FRs are present in plasma membranes as well as membranes surrounding organelles; refs. 5, 23) in HeLa-IU ${ }_{1}-L F$ cells demonstrated they had a significant (approximately ninefold) increase in FR protein compared with that of HeLa-IU $\mathrm{H}_{1}-\mathrm{HF}$ cells. Scatchard analysis of folate binding to FRs on intact cells (3) revealed values of $2.2 \times 10^{4}$ molecules of FR/cell (or 22 molecules of FR $/ \mu \mathrm{m}^{2}$ cell surface area) for HeLa-IU $\mathrm{I}_{1}-\mathrm{HF}$ cells (3) and $6.0 \times 10^{6}$ molecules of FR/cell (or $2412 \mathrm{~mol}-$ ecules of FR $/ \mu \mathrm{m}^{2}$ cell surface area) for HeLa-IU ${ }_{1}-L F$ cells. Thus, HeLa-IU $U_{1}-L F$ cells also exhibited a true increase in FRs and folate-binding capacity compared with HeLa$\mathrm{IU}_{1}-H F$ cells. However, the mRNA was only increased approximately twofold in HeLa-IU $\mathrm{I}_{1}-L F$ cells compared

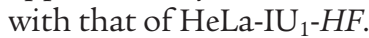

Next, the kinetics of FR mRNA as well as FR protein expression were determined as a function of time after HeLa-IU $-H F$ cells were placed in low-folate media over 12 weeks of study. Western blot studies at the end of each week demonstrated a steady progressive increase in FR expression that plateaued by the 10th-12th week (Figure 1a). Binding of radiolabeled folate to intact cells and Scatchard analysis also revealed a progressive increase in FRs per cell as a function of time (Figure 1b). These data complemented each other to confirm a true net increase in FR protein upon shifting of HeLa-IU $\mathrm{U}_{1}-\mathrm{HF}$ cells to low-folate media. By contrast, there was a relatively small (at most 2.5-fold) increase in FR mRNA that plateaued by the fourth week (Figure 1c). Thus, the increase in mRNA could not account for the progressive and much higher fold increase in FR protein expression that plateaued much later. These results suggested that the primary mechanism underlying the striking upregulation of FRs in these cells would be found at the translational or post-translational level.

Because we demonstrated that the interaction of a cytosolic hnRNP E1 with an 18-base cis-element in the $5^{\prime}$-UTR of FR mRNA was essential for translation of FRs $(13,14)$, we determined if the observed upregulation of FR was due to induction of hnRNP E1 under the experimental conditions. The data (Figure 1d) indicated that there was no significant change in the expression of the hnRNP E1 in HeLa-IU ${ }_{1}-L F$ versus HeLa-IU ${ }_{1}-H F$ cells.

Analysis of FR mRNA isoforms by RT-PCR (18) indicated that HeLa-IU ${ }_{1}-H F$ cells expressed only FR- $\alpha$ mRNA and that this isoform comprised $95 \%$ of the species in HeLa-IU ${ }_{1}-L F$ cells. FR- $\beta$ mRNA comprised the remainder in HeLa-IU $\mathrm{U}_{1}-L F$ cells (not shown). Nuclear run-on studies confirmed that the transcription rate of FR genes (relative to the transcription rate of $\beta$-actin) in HeLa-IU $1-L F$ cells was 1.4-fold more than that of HeLa$\mathrm{IU}_{1}-H F$ cells (Figure $2 \mathrm{a}$ ). The half-life $\left(t_{1 / 2}\right)$ of FR mRNA in HeLa-IU $1-H F$ and HeLa-IU $U_{1}-L F$ cells was 6.6 hours and 6.4 hours, respectively (Figure $2 \mathrm{~b}$ ); under comparable conditions, the $t_{1 / 2}$ of $\beta$-actin increased from 8.6 hours to 9.3 hours, respectively. This indicated no significant change in the rate of degradation of FR mRNA between HeLa-IU $\mathrm{U}_{1}-H F$ and HeLa-IU $\mathrm{U}_{1}-L F$ cells. Thus, the relatively small increase in transcription rate could account for the observed (albeit small) increase in net FR mRNA in HeLa-IU ${ }_{1}-L F$ cells. But these parameters alone could not account for the observed upregulation of FR protein in $\mathrm{HeLa}-\mathrm{IU}_{1}-L F$ cells.

The kinetics of synthesis and degradation of FR protein was determined by quantitative recovery and isolation of $\left.{ }^{35} \mathrm{~S}\right] \mathrm{FR}$ from other biosynthetically labeled cellular proteins using anti-placental FR antiserum (which binds GPI-anchored FR even in the presence of folates; refs. 3, 27) to immunoprecipitate FRs in $\mathrm{HeLa}-\mathrm{IU}_{1}$ cells. As expected, a single $38-\mathrm{kDa}$ species of $\left[{ }^{35} \mathrm{~S}\right] \mathrm{FR}$ was identified when $\mathrm{HeLa}-\mathrm{IU}_{1}-L F$ cells were immunoprecipitated after a chase with cysteine-free media of up to 4 hours (Figure 2c). The recovery of $\left[{ }^{35} \mathrm{~S}\right] \mathrm{FR}$ was virtually complete, as further addition of antiserum to the supernatant (after prior immunoprecipitation of $\left[{ }^{35} \mathrm{~S}\right] \mathrm{FR}$-antibody complexes with IgGsorb) failed to immunoprecipitate additional $\left.{ }^{35} \mathrm{~S}\right] \mathrm{FR}$ (Figure $2 \mathrm{~d}$, lane 2). Analysis of de novo synthesis of $\left[{ }^{35} \mathrm{~S}\right] \mathrm{FR}$ (Figure $2 \mathrm{c}$ ) revealed a progressive conversion of the $34,000-\mathrm{M}_{\mathrm{r}}$ species into a $38,000-\mathrm{M}_{\mathrm{r}}$ species, consistent with glycosylation of FR as a function of time (33). Addition of monensin, an inhibitor of N-glycosylation (34), to cells during biosynthetic labeling abolished conversion to the higher- $\mathrm{M}_{\mathrm{r}}$ species (Figure 2e, lane 2). In addition, treatment of $38-\mathrm{kDa}\left[{ }^{35} \mathrm{~S}\right] \mathrm{FR}-a n t i b o d y$ complexes with glycopeptidase $\mathrm{F}$ led to complete conversion to a lower- $\mathrm{M}_{\mathrm{r}}$ species as described (33). Finally, anti-placental FR antisera immunoprecipitated nascent FR polypeptides $(28-29 \mathrm{kDa})$ generated by in vitro translation of FR mRNA in the absence of microsomes (17), consistent with its specificity for peptide epitopes in FRs. Together, these studies confirmed that both ${ }^{35} \mathrm{~S}-$ labeled species (measured as picomoles of $\left[{ }^{35} \mathrm{~S}\right] \mathrm{cys}-$ teine) immunoprecipitated with anti-placental FR antiserum were related to FRs.

Compared with HeLa-IU $\mathrm{I}_{1}-H F$ cells, in which FRs were degraded with a $t_{1 / 2}$ of 32 hours, the $t_{1 / 2}$ of FR degradation in HeLa-IU $\mathrm{I}_{1}-L F$ cells was 28.5 hours (Figure 2f). This negligible alteration in the rate of degradation of FRs could not account for the observed upregulation of FRs. However, the rate of incorporation of $\left[{ }^{35} \mathrm{~S}\right]$ cysteine into FRs of HeLa-IU $\mathrm{U}_{1}-\mathrm{HF}$ cells was $0.0053 \mathrm{pmol} / \mathrm{mg} /$ hour, whereas this value was $0.087 \mathrm{pmol} / \mathrm{mg} /$ hour in HeLa-IU $1-L F$ cells (Figure $2 \mathrm{~g}$ ); the proportionate increase in incorporation of $\left[{ }^{35} \mathrm{~S}\right]$ cysteine into FRs in these cells is shown in Figure $2 \mathrm{~h}$. This 16 -fold increase in rate of synthesis of FRs in HeLa-IU ${ }_{1}-L F$ cells compared with that in HeLa-IU $\mathrm{U}_{1}-H F$ cells strongly suggested that the likely dominant regulatory mechanism that accounted for stable FR upregulation in low-folate media was translational in nature. Because 2.7 -fold more $\left[{ }^{35} \mathrm{~S}\right]$ hydrophilic FRs were released into the media from $\left[{ }^{35} \mathrm{~S}\right]$ hydrophobic FRs in HeLa-IU ${ }_{1}-L F$ cells than in HeLa-IU ${ }_{1}-H F$ cells $(0.035$ versus $0.013 \mathrm{pmol} / \mathrm{mg}$, 

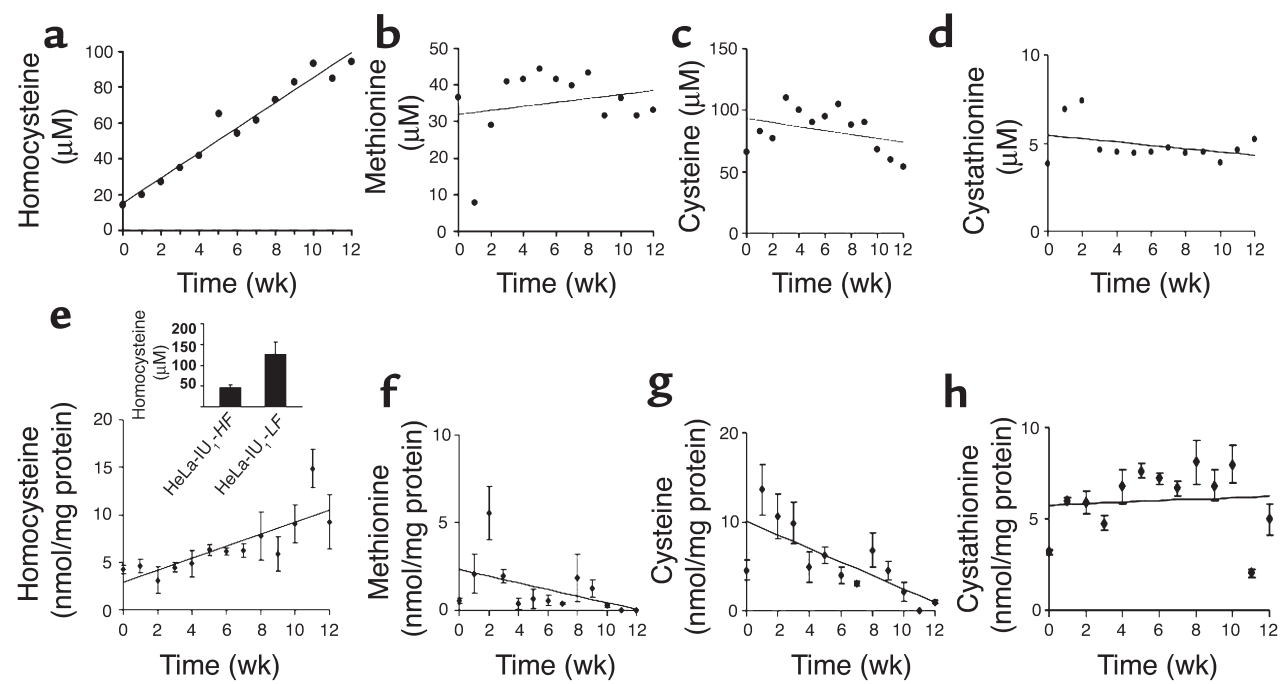

\section{Figure 3}

Concentrations of homocysteine, methionine, cysteine, and cystathionine in the growth media and within HeLa-IU $\mathrm{U}_{1}-\mathrm{HF}$ cells that were propagated in low-folate media over 12 weeks. (a-h) Profiles of the concentrations of total homocysteine (a and $\mathbf{e})$, methionine (b and f) total cysteine ( $\mathbf{c}$ and $\mathbf{g}$ ), and cystathionine ( $\mathbf{d}$ and $\mathbf{h}$ ) in the growth media (top panels) and intracellularly (bottom panels) as a function of time after HeLa-IU $1-H F$ cells were propagated in low-folate media. HeLa-IU $-H F$ cells $\left(1 \times 10^{7}\right)$ were fed twice a week with lowfolate media. Each week, after they had been in contact with media for 3 days, the supernatants and cell pellets were analyzed for metabolites by gas chromatography-mass spectroscopy.

respectively), it was unlikely that a change in steadystate release of FRs from cells contributed to overall upregulation of FRs in HeLa-IU $-L F$ cells.

Reduced availability of 5-methyl-tetrahydrofolate intracellularly inactivates methionine synthase (EC 2.1.1.3), which catalyzes the conversion of homocysteine to methionine (35). The resulting substrate build-up of homocysteine leads to its movement out of the cell (20), after which it can be measured by a sensitive capillary gas chromatography-mass spectrometry assay (29). Published data by Kolhouse et al. (19) on the kinetics of release of homocysteine from cultured human fibroblasts indicated a progressive accumulation of homocysteine in the media from a baseline of $2 \mu \mathrm{M}$ homocysteine to $4.25 \mu \mathrm{M}$ (week 2), $8.75 \mu \mathrm{M}$ (week 4), $11 \mu \mathrm{M}$ (week 6), and $13 \mu \mathrm{M}$ (week $8)$. However, the rate of development of folate deficiency is likely to be altered by several variables, including the number and proliferative rate of cells, the amount of media used for culture, and the frequency of media changes. Because HeLa-IU $\mathrm{U}_{1}-L F$ cells exhibited biochemical evidence of folate deficiency with a marked increase of homocysteine in the media of these cells, we measured the temporal accumulation of total homocysteine and related metabolites while HeLa-IU $\mathrm{I}_{1}-H F$ cells were propagated for 12 weeks in low-folate media. There was a steady rise of total homocysteine released into the media, indicating the progressive development of cellular folate deficiency (Figure 3a). Of significance, this rise in homocysteine resembled the steady rise in the expression of FR (Figure 1, a and b). By contrast, the concentration of a panel of metabolites that could poten- tially be modulated in folate deficiency (total cysteine, cystathionine, and methionine) was not significantly changed from baseline values (Figure 3, b-d).

When HeLa-IU ${ }_{1}-H F$ cells were propagated in lowfolate media as a function of time with rigorous steps taken to prevent the movement of homocysteine out of cells, the intracellular homocysteine was noted to progressively increase (Figure 3e). As also noted in Figure 3 e (inset), when the intracellular homocysteine was measured in cells stably propagated in high-folate versus low-folate medium, the concentration of homocysteine increased 2.7-fold in HeLa-IU ${ }_{1}-L F$ cells compared with HeLa-IU $1-H F$ cells. By contrast, the intracellular content of cystathionine was unchanged, whereas methionine and cysteine were progressively reduced as a function of time (Figure 3, f-h). Taken together, these data suggested that the accumulation of homocysteine within cells (from inhibition of methionine synthase [EC 2.1.1.3]) could have consequences for gene expression.

Modulation of the FR mRNA cis-element and hnRNP E1 interaction by homocysteine. Because the thiol amino acid homocysteine can covalently bind cysteine residues to modify protein function (36), we tested the hypothesis that homocysteine could increase RNA-protein interactions and lead to upregulation of FRs. As demonstrated in Figure 4, a and b, when analyzed by electrophoretic mobility gel-shift assays using radiolabeled 18-base FR- $\alpha$ mRNA cis-element and cytosolic extracts containing hnRNP E1 from HeLa-IU 1 cells, dl-homocysteine, l-cysteine, and dl-homocysteine thiolactone stimulated a dose-dependent increase in RNA-protein complex signals. By contrast, l-methionine at equimo- 
lar concentrations had no effect, similar to the negative control consisting of dl-homocystine (an oxidized form of homocysteine). In addition, other reducing agents, glutathione, DTT, and $\beta$-mercaptoethanol also had a positive influence in generating a dose-dependent increase in the RNA-protein complex. Similar findings were also demonstrated with a highly purified preparation of human placental trans-factor (14), indicating that these data were not restricted to hnRNP E1 protein derived from cervical carcinoma cells.

Although several reduced thiols can induce the RNAprotein interaction (Figure 4 , $a$ and $b$ ), the data on the concentrations of reduced thiols in the media and within cells during the development of folate deficiency indicated that the only metabolite of physiological relevance and that increased with time was homocysteine (Figure 3). The basal extracellular concentration of total cysteine in folate-replete cells was higher than total homocysteine (Figure 3, c versus a) and sufficiently high to increase RNA-protein interactions (Figure 4a). However, because the concentration of total cysteine in the media remained unchanged with time (Figure 3c), but decreased progressively within cells (Figure $3 \mathrm{~g}$ ) during the development of folate deficien$c y$, the evidence argued against a significant role for cysteine in FR upregulation (Figure 1). By contrast, the data from Figures 3 , a and e, and 4 supported the possibility of a role for homocysteine that accumulated during folate deficiency and could increase RNA-protein interactions, which facilitates translational upregulation (14). In this context, HeLa-IU $\mathrm{I}_{1}-\mathrm{HF}$ cells contained $47 \mu \mathrm{M}$ of homocysteine $/ 10^{6}$ cells whereas HeLa-IU ${ }_{1}-L F$ cells contained $126 \mu \mathrm{M}$ homocysteine $/ 10^{6}$ cells. When these data are related to the gel-shift assays
(Figure 4a), there is a clear RNA-protein signal, indicative of interaction between the trans-factor and cis-element at a concentration of $100 \mu \mathrm{M}$ of homocysteine, with a much lesser signal at lower concentrations of homocysteine. Collectively, these studies indicate that the 2.7-fold increase in intracellular homocysteine concentration in HeLa- $\mathrm{IU}_{1}-L F$ cells can induce changes in the hnRNP E1 protein, leading to a facilitation of binding to the 18-base cis-element of FR mRNA leading to increased biosynthesis of FRs in these cells.

Because quenching of the interaction of the cis-element and hnRNP E1 inhibits the translation of FRs in vitro (13), we also hypothesized that any agent that increased the interaction would likely facilitate the increase in translational synthesis of FRs. However, this could not be confirmed by in vitro translation assays, because all such assays require the addition of $20 \mathrm{mM}$ DTT, and even $50 \mu \mathrm{M}$ DTT had a significant positive effect (Figure 4). Therefore, it was highly unlikely that any additive effects of micromolar concentrations of homocysteine on FR synthesis would be uncovered by this assay.

Experimental modulation of intracellular homocysteine and effects on FR biosynthesis. To evaluate the direct effects of homocysteine (independent of changes in the concentration of cysteine) on the biosynthesis of FRs and the interaction between the cis-element and trans-factor/ hnRNP E1, we used short-term experiments in which homocysteine was added to cells and the effects on biosynthesis of FR as well as on cis-element driven reporter constructs were determined. For these experiments, we needed to determine precisely the extent of accumulation of homocysteine within these cells at various extracellular pharmacological concentrations of
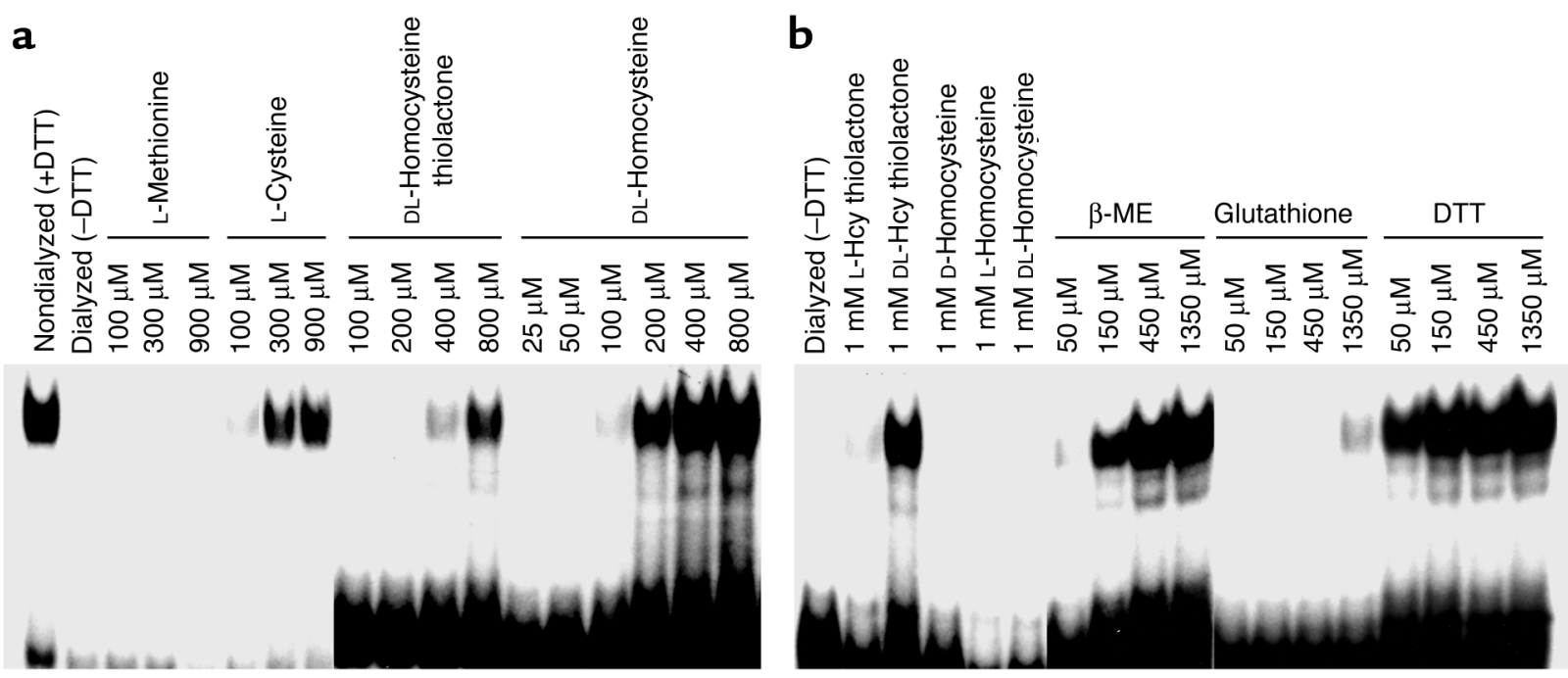

Figure 4

Gel-shift assays of the interaction of 18-base cis-element from the 5'-UTR of FR- $\alpha$ mRNA and the $43-k D a$ hnRNP E1 by homocysteine and other agents. ( $\mathbf{a}$ and $\mathbf{b})\left[{ }^{32} \mathrm{P}\right]$ cis-element $(10,000 \mathrm{cpm})$ was allowed to react with $20 \mu \mathrm{g}$ dialyzed S-100 fraction from HeLa-IU ${ }_{1}-H_{F}$ cells with indicated concentrations of I-methionine, I-cysteine, dl-homocysteine (Hcy) thiolactone, dl-homocysteine, d-homocystine, I-homocystine, $\beta$-mercaptoethanol ( $\beta$-ME), glutathione, or DTT, and RNA-protein complexes were separated by native PAGE followed by autoradiography. Cell extracts were dialyzed in buffer without DTT. $\beta$-ME, $\beta$-mercaptoethanol. 

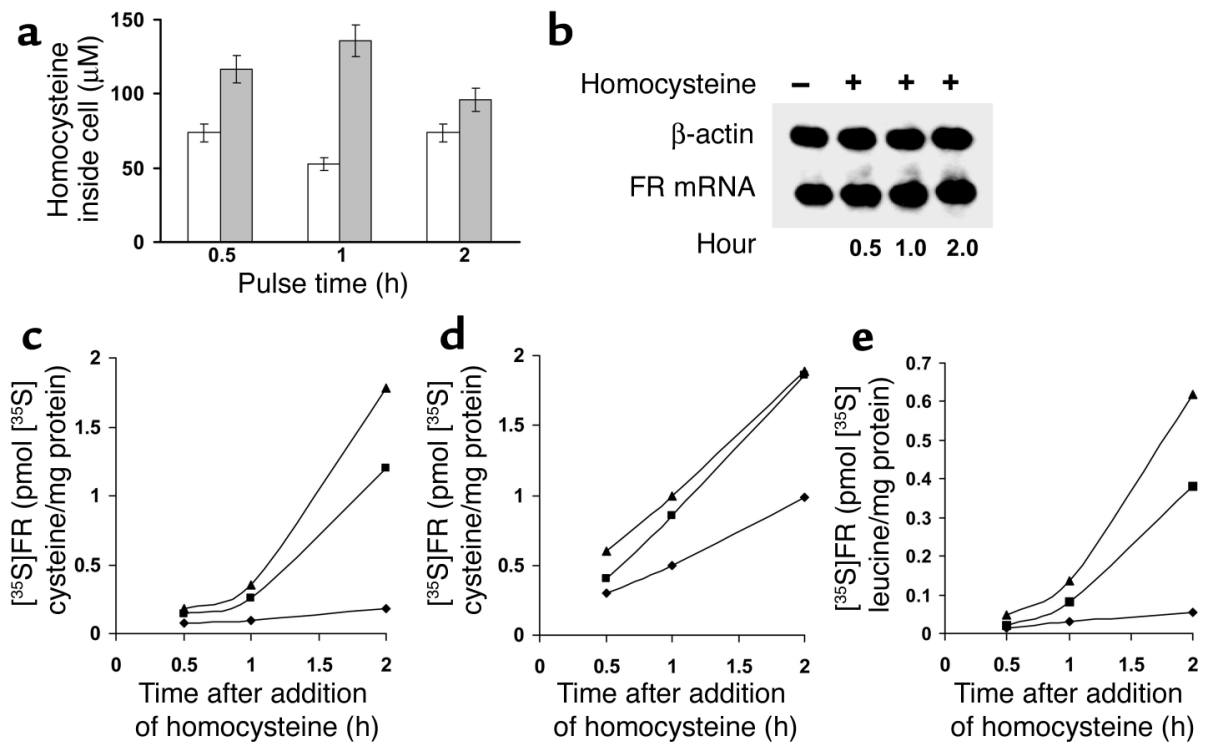

\begin{abstract}
Figure 5
Quantitation of the extent of influx of extracellular homocysteine into HeLa-IU $U_{1}$ cells and the effects of accumulated homocysteine on the expression of FR mRNA and the biosynthesis of FR. (a) Determination of the concentration of intracellular homocysteine after incubation of HeLa-IU 1 -HF cells with $500 \mu \mathrm{M} \mathrm{dl-homocysteine} \mathrm{(white} \mathrm{bars)} \mathrm{or} \mathrm{1,000} \mu \mathrm{M}$ dl-homocysteine (gray bars) for the indicated time. (b) Northern blots of total cellular mRNA $(3 \mu \mathrm{g})$ from HeLa-IU $\mathrm{H}_{1}-H F$ cells exposed to 1,000 $\mu \mathrm{M}$ dl-homocysteine for various times and probed with FR mRNA and $\beta$-actin mRNA. (c-e) Stimulation of FR synthesis using $\left[{ }^{35} \mathrm{~S}\right]$ cysteine $(\mathbf{c}$ and $\mathbf{d})$ or $\left[{ }^{3} \mathrm{H}\right]$ leucine $(\mathbf{e})$ in cultured HeLa-IU ${ }_{1}-H F$ cells (c and $\mathbf{e}$ ) and HeLa-IU $1-L F$ cells (d) by various concentrations of homocysteine as a function of time. No dl-homocysteine (diamonds), 500 $\mu \mathrm{M}$ dl-homocysteine (squares), or $1,000 \mu \mathrm{M}$ dl-homocysteine (triangles) was added to cultured cells during incubation with [ $\left.{ }^{35} \mathrm{~S}\right]$ cysteine or $\left[{ }^{3} \mathrm{H}\right]$ leucine. $\left[{ }^{35} \mathrm{~S}\right]$ FR or $\left[{ }^{3} \mathrm{H}\right]$ FR was immunoprecipitated with anti-FR antiserum and IgGsorb and radioactivity was measured. The data from three independent experiments (with each data point carried out in triplicate) were pooled. There was less than $10 \%$ variation from this mean among the three independent experiments.
\end{abstract}

homocysteine. Accordingly, we separated the cell-associated homocysteine from the higher concentrations of homocysteine extant in the supernatant by passing the mixture of cells and supernatant over silicone fluid (see Figure $3 e$, inset). Figure 5 a shows the results of experiments designed to quantitate the amount of extracellularly added homocysteine that entered $\mathrm{HeLa}_{\mathrm{IU}}-\mathrm{IF}$ cells. These results indicate that approximately $13 \%$ of homocysteine entered cells at concentrations of both $500 \mu \mathrm{M}$ and $1,000 \mu \mathrm{M}$ of extracellular homocysteine. This value differs substantially from published values of approximately $2 \%$ in U-937 human histiocytic cells (20) and can perhaps be explained by cell type differences. However, the stringency of methods designed to limit efflux of homocysteine from cells was far more intentional in the present studies.

Accordingly, HeLa-IU $1-H F$ cells that were first prewashed with large volumes of wash-buffer to effect efflux of endogenous intracellular homocysteine (see Methods) were exposed for periods up to 2 hours to $500 \mu \mathrm{M}$ or $1,000 \mu \mathrm{M}$ of homocysteine and the extent of $\left.{ }^{35} \mathrm{~S}\right]$ FR synthesis was determined. Homocysteine at these concentrations did not alter the mRNA of FR in HeLa-IU $\mathrm{U}_{1}-H F$ (Figure $5 \mathrm{~b}$ ) or HeLa-IU ${ }_{1}-L F$ cells (not shown) during these short-term experiments; therefore, any effects of homocysteine in stimulating FR biosynthesis could be attributed to effects primarily at the translational level. As shown in Figure 5c, there was a significant dose-dependent increase in the synthesis of $\left[{ }^{35} \mathrm{~S}\right] \mathrm{FR}$ following the addition of homocysteine to HeLa-IU ${ }_{1}-H F$ cells. Compared with control (no addition of homocysteine), exposure of HeLa-IU $\mathrm{I}_{1}-\mathrm{HF}$ cells to $1,000 \mu \mathrm{M}$ homocysteine for 2 hours led to an eightfold increase in synthesis of $\left.{ }^{35} \mathrm{~S}\right] \mathrm{FR}$ (Figure 5c). Similar stimulatory effects of homocysteine were also observed in $\mathrm{HeLa}-\mathrm{IU}_{1}-L F$ cells, although the effects of $500 \mu \mathrm{M}$ and $1,000 \mu \mathrm{M}$ were similar (Figure $5 \mathrm{~d}$ ). Because the effects of $500 \mu \mathrm{M}$ and 1,000 $\mu \mathrm{M}$ homocysteine on FR biosynthesis were monitored by $\left[{ }^{35} \mathrm{~S}\right]$ cysteine incorporation into FR, it was possible that this apparent stimulation of $\left[{ }^{35} \mathrm{~S}\right]$ cysteine incorporation into FR by homocysteine was driven by the fact that cells were starved of cysteine prior to the biosynthetic studies. Accordingly, we determined if homocysteine had similar stimulatory effects on FR biosynthesis when $\left[{ }^{3} \mathrm{H}\right]$ leucine was used instead of $\left[{ }^{35} \mathrm{~S}\right]$ cysteine. The results (Figure 5e) revealed a profile similar to that obtained with $\left[{ }^{35} \mathrm{~S}\right]$ cysteine, thereby eliminating the possibility of a role of cysteine starvation in the observed effects of homocysteine in stimulating FR biosynthesis. Of significance, the concentrations of homocysteine achieved intracellularly (Figure 5a) are well within the range of increasing cis-element and trans-factor/hnRNP E1 interaction on gel-shift assays (Figure 4, a and b) and can explain the stimulation of biosynthesis of FRs (Figure 5, c-e). 
Homocysteine exerted a stimulatory effect on cellular FR biosynthesis within 30 minutes. This duration is much shorter than the observed effects of homocysteine on transcriptional regulation of many other genes, which required 6 hours of exposure (37). Furthermore, our documentation that homocysteine did not induce changes in FR mRNA levels supported the conclusion that the effect of homocysteine was primarily in modulating RNA-protein interactions. Thus, in the model involving a gradual development of nutritional folate deficiency, the data strongly argued for a causal role for homocysteine in translational upregulation of FRs. Collectively these data supported the conclusion that the build-up of homocysteine in nutritional folate deficiency stimulated the interaction of a specific cis-element and hnRNP E1 that led to the translational upregulation of FRs.

Characterization of homocysteine-responsiveness by the 18base cis-element using reporter constructs. Experiments were designed to characterize the functional role of the 18base cis-element in reacting with the trans-factor/ hnRNP E1 in HeLa-IU $U_{1}$ cells in which the concentration of homocysteine was modulated. In the first method, the intracellular homocysteine concentration was modulated by the extracellular folate concentration (using HeLa-IU $\mathrm{I}_{1}-H F$ or HeLa-IU $-L F$ cells) (see Figure $3 e$ and inset). After cotransfection of plasmids bearing CAT and $\beta$-galactosidase reporter genes, measurement of the CAT and $\beta$-galactosidase activities in the cell extracts allowed for monitoring of transfection efficiencies in HeLa-IU $\mathrm{I}_{1}-H F$ and HeLa-IU ${ }_{1}-L F$ cells. Surprisingly, cotransfection led to expression of $\beta$-galactosidase (per milligram protein) that was 2.5 - to 4-fold higher in $\mathrm{HeLa}_{-} \mathrm{IU}_{1}-H F$ cells than in $\mathrm{HeLa}_{-} \mathrm{IU}_{1}-L F$ cells. This indicated that HeLa-IU $-L F$ cells had lower transfection efficiencies than HeLa-IU ${ }_{1}-H F$ cells. Under these conditions, the pCAT $(+c i s)$ construct yielded almost equal levels of CAT expression in both cell lines; this experiment was carried out six times with similar results. Thus, CAT expression from pCAT (+cis) was much higher in $\mathrm{HeLa}_{-} \mathrm{IU}_{1}-L F$ cells than in $\mathrm{HeLa}_{-} \mathrm{IU}_{1}-H F$ cells. Because there was negligible CAT expression in HeLa-IU $-L F$ and HeLa-IU $1-H F$ cells transfected with pCAT (-cis), which was devoid of the cis-element (Figure 6a), the observed CAT expression from PCAT (+cis) in these cells was localized to the 18-base cis-element.
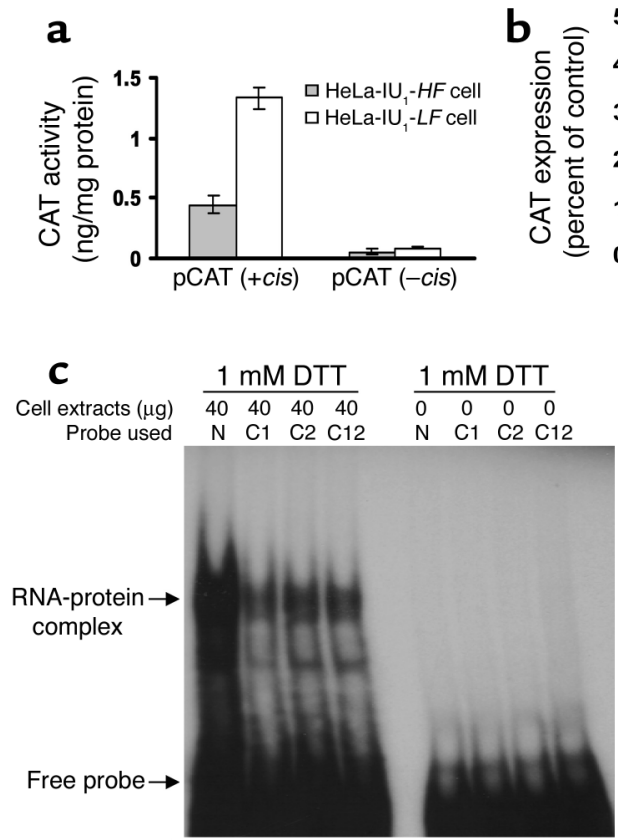
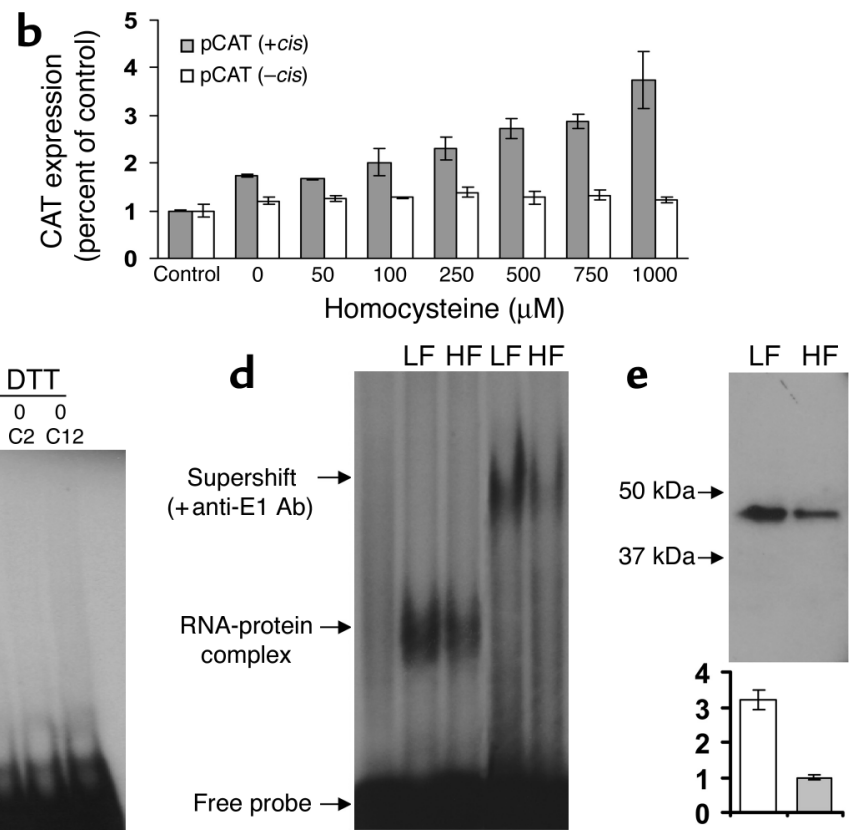

\section{Figure 6}

Confirmation of the critical nature of the FR mRNA cis-element and the hnRNP E1 interaction in mediating homocysteine effects using a combination of reporter genes, site-directed mutagenesis, gel-supershift assays, and UV cross-linking studies. (a) Expression of CAT reporter genes in HeLa-IU $1-H F$ cells (gray bars) and HeLa-IU $1-L F$ cells (white bars) that were transfected with pCAT (+cis) and pCAT ( -cis). The terms (+cis) and (-cis) refer to the presence or absence or the 18-base cis-element in the plasmid. The data are normalized for transfection efficiency deter-

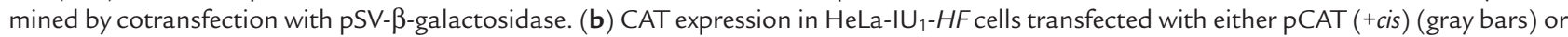
PCAT (-cis) (white bars) before exposure to increasing concentrations of homocysteine for 1 hour before being harvested for assay. pSV- $\beta$ galactosidase was used as an internal control. (c) Gel-shift assay of RNA-protein complexes in the presence of 1 mM DTT. Radiolabeled 18base cis-element $(\mathrm{N})$ or its mutants $(\mathrm{C} 1, \mathrm{C} 2$, and $\mathrm{C} 12)$ were allowed to react with cytosolic hnRNP E1 from HeLa-IU 1 cells. (d) Gel-shift assay and supershift analysis to characterize the identity of the protein within the RNA-protein complexes that formed in the presence of cellular homocysteine concentrations in HeLa-IU 1 -LF cells (denoted as LF) and HeLa-IU - $_{1}$ FF cells (denoted as HF) using nonimmune and anti-hnRNP E1 antiserum (shown by top arrow). (e) SDS-PAGE of UV cross-linked RNA-protein complexes induced in response to the higher cellular lev-

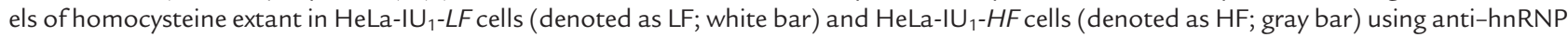
E1 antiserum (top) and the corresponding ratio of radioactivity immunoprecipitated (bottom). 
Because HeLa-IU $-L F$ cells had a 2.7-fold greater concentration of intracellular homocysteine than HeLa-IU $\mathrm{I}_{1}-\mathrm{HF}$ cells (Figure 3e, inset) at levels at which RNA-protein interaction could be demonstrated (Figure 4a), these results continued to highlight the likely importance of the 18-base cis-element in homocysteine responsiveness.

To further confirm that the cis-element was integral to homocysteine responsiveness, we sought to determine if short-term exposure of HeLa-IU $\mathrm{I}_{1}-\mathrm{HF}$ cells transfected with pCAT $(+c i s)$ to progressively increasing intracellular concentrations of homocysteine (for 1 hour) led to a predictable dose response compared with cells transfected with pCAT (-cis). The results (Figure $6 \mathrm{~b})$ indicated that whereas HeLa-IU $\mathrm{I}_{1}-H F$ cells transfected with PCAT (-cis) exhibited no increase in signal with increasing concentrations of homocysteine, those cells transfected with pCAT $(+c i s)$ exhibited dose responsiveness to homocysteine. When these results were correlated with the actual measurements of intracellular homocysteine under similar experimental conditions (Figure 5a), the concentrations of intracellular homocysteine achieved following incubation with 50, $100,250,500,750$, and $1,000-\mu \mathrm{M}$ of dl-homocysteine were $6.5,13,32.5,65,97.5$, and $130 \mu \mathrm{M}$, respectively. Furthermore, when these results are compared with those values of homocysteine used in gel-shift experiments to demonstrate RNA-protein interactions (Figure 4), it is readily apparent that the concentrations achieved intracellularly were well within the range for endogenous trans-factor/hnRNP E1 (Figure 1d) to interact with the 18-base cis-element proximal to the CAT gene to give the observed signals. Thus, all of these data (Figures 1-6) can now be reconciled to explain the progressive increase in FR upregulation when the extracellular folate concentration is limited. On the basis of these experiments, we conclude that the data demonstrate that the accumulated homocysteine within cells during folate deficiency is sufficient to trigger the interaction of the trans-factor/hnRNP-E1 with the 18-base cis-element within the $5^{\prime}$-UTR of FR mRNA to result in translational upregulation of FRs.

Next we determined if point mutation of the 18base cis-element sequence would abrogate RNA-protein complex formation in the induced state. Based on characterization of the RNA-protein interaction, we had suggested that the CUCC motif in the 18-base ciselement sequence [CUCC(AU)-4-6-bases-CUCC] could be critical in binding hnRNP E1 $(13,14)$. Accordingly, we mutated cytidine $5^{\prime}$-triphosphate at specific positions in the 18-mer cis-element (detailed in Methods) and compared the binding to hnRNP E1. The results (Figure $6 \mathrm{c}$ ) revealed that a point mutation in either the first or second (or both) CUCC motif in the 18-base cis-element led to a reduction in RNA-protein complex formation in the induced state. This verified that the interaction of endogenous hnRNP E1 was critically dependent on the integrity of the 18base cis-element in the 5'-UTR of FR mRNA and confirmed our earlier predictions (13).
Next we determined if more radiolabeled cis-element interacted with endogenous hnRNP E1 from HeLa$\mathrm{IU}_{1}-L F$ cells than from HeLa-IU ${ }_{1}-H F$ cells because of the higher cellular concentration of homocysteine of folate-depleted cells (Figure 3e). We used UV cross-linking of the RNA-protein complexes (13), which allowed us to eliminate the use of an exogenous reducing agent to trigger RNA-protein complex formation (which would confound analysis of the independent effect of intracellular homocysteine). Accordingly, cytosolic hnRNP E1 from HeLa-IU $1-H F$ and HeLa-IU ${ }_{1}-L F$ cells that was isolated under conditions that avoided efflux of cellular homocysteine (see Methods) was incubated with $\left[{ }^{32} \mathrm{P}\right] c i s$-element, and after cross-linking of RNAprotein complexes (13), the mixture was allowed to react with anti-hnRNP E1 antiserum or nonimmune serum and was analyzed further. The results of gel-shift assay, immunoprecipitation, and SDS-PAGE of the anti-hnRNP E1 antiserum-bound RNA-protein complexes in HeLa-IU $\mathrm{I}_{1}-L F$ cells and HeLa-IU $\mathrm{U}_{1}-H F$ cells are shown in Figure 6, d and e. These concordant results demonstrated that the greater amount of homocysteine present in HeLa-IU $\mathrm{I}_{1}-L F$ cells (Figure $3 e$ ) led to a greater interaction of the cis-element and hnRNP E1, compared with the data from HeLa-IU $\mathrm{I}_{1}-H F$ cells. This is shown by the stronger signal in the gel-shifted band, a greater amount of immunoprecipitated material by radioactive counts, and a stronger signal on SDS-PAGE in the sample from HeLa-IU $U_{1}-L F$ cells. Moreover, the supershift of the signal with anti-hnRNP E1 antiserum (Figure 6d) indicated that the $\left[{ }^{32} \mathrm{P}\right] c i s$-element RNAprotein complex contained hnRNP E1.

When we used RNA cis-element probes with very high specific activity in experiments similar to that shown in Figure 4, the lowest concentrations of homocysteine that could stimulate interaction of the cis-element and trans-factor/(hnRNP E1) were $20-25 \mu \mathrm{M}$, values that were consistent with mild folate deficiency $(1,30)$. This suggests that smaller concentrations of intracellular homocysteine have the potential to modulate the interaction, indicating that this regulatory mechanism is operative before a much higher "critical threshold" concentration is achieved. The data (Figure 6, $\mathrm{d}$ and e) support this conclusion. Such a system probably allows for regulation of FRs even during short-term deprivation of dietary folate. Future studies will focus on characterizing the concordance of fluctuating intracellular homocysteine concentrations with changes in FR expression in real-time.

Mechanism(s) of downregulation of FRs during acute reversal of folate deficiency. As demonstrated in Figure 4, methionine did not stimulate the RNA-protein interaction. This predicts that reversal of folate deficiency, which is associated with conversion of homocysteine to methionine, would result in less RNA-protein interaction and downregulation of FRs. So in the next experimental system, HeLa-IU $1-L F$ cells were abruptly exposed to high-folate media and over the ensuing 24 hours the rate of FR biosynthesis and concentrations 
of total homocysteine and other metabolites were determined. Because of a good correlation between the intracellular and extracellular homocysteine concentrations (Figure 3, a and e), the rate of accumulation of homocysteine in the growth media as a function of time after acute reversal of folate deficiency was used as a surrogate marker of intracellular homocysteine. Quantitative measurements indicated that rapid reversal of folate deficiency led to a parallel reduction in FR biosynthesis (Figure 7a) and total homocysteine (Figure $7 \mathrm{~b}$ ) so that by 24 hours, both parameters approached values found in folate-replete cells. Thus, there was a prompt reduction in total homocysteine in the media from $108 \mu \mathrm{M}$ (basal in low-folate) to $43 \mu \mathrm{M}$ by 8 hours, and $21 \mu \mathrm{M}$ by 24 hours (the basal value with folate-replete cells was $14 \mu \mathrm{M})$. Once again, there were no major changes in the concentrations of methionine, total cysteine, and cystathionine (Figure 7, c-e).

Previous data from our laboratory (38) predicted that at the high concentrations of folic acid in media used to propagate $\mathrm{HeLa}-\mathrm{IU}_{1}-H F$ cells, folic acid could easily passively diffuse into cells. Therefore, rapid replenishment of folic acid to folate-deficient HeLa-IU $\mathrm{I}_{1}-L F$ cells (Figure 7) introduced a new variable (folic acid) that could influence RNA-protein interaction. Neither folic acid nor 5 methyl-tetrahydrofolate had any direct effect in increasing the RNA-protein interaction in the absence of reducing agents (data not shown). However (as shown in Figure 7f), in the presence of homocysteine, increas- ing concentrations of folic acid, but not 5-methyltetrahydrofolate, effected a dose-dependent reduction in RNA-protein interaction (at concentrations within the context of the experiment leading to Figure 7, a-e). The capacity of folic acid to modulate the RNA-protein interaction in gel-shift assays could be artificially improved by a reduction in the concentration of homocysteine (data not shown). These in vitro data predict that with more severe folate deficiency (and proportionately higher homocysteine buildup) there would be less capacity of folic acid to directly dissociate the RNAprotein interaction (and induce downregulation of FRs). Conversely, with milder folate deficiency, the direct effect of folic acid in quenching RNA-protein interaction would be more prominent. However, because folic acid is not naturally found in human plasma, it is quite unlikely that any of these (putative) effects of folic acid on translational up- or downregulation have any physiologic significance. Furthermore, folic acid that is administered orally to folate-deficient humans in pharmacological doses (1 mg per day) is converted to 5methyl-tetrahydrofolate during absorption, and this is the form that is taken up by cells of peripheral tissues (1). Nevertheless, if given intravenously, the folic acid that diffuses into cells (38) could easily contribute to acute disruption of RNA-protein complexes and lead to downregulation. In this context, it is possible that other (as-yet-undefined) intracellular folates may also contribute to translational downregulation of FRs.
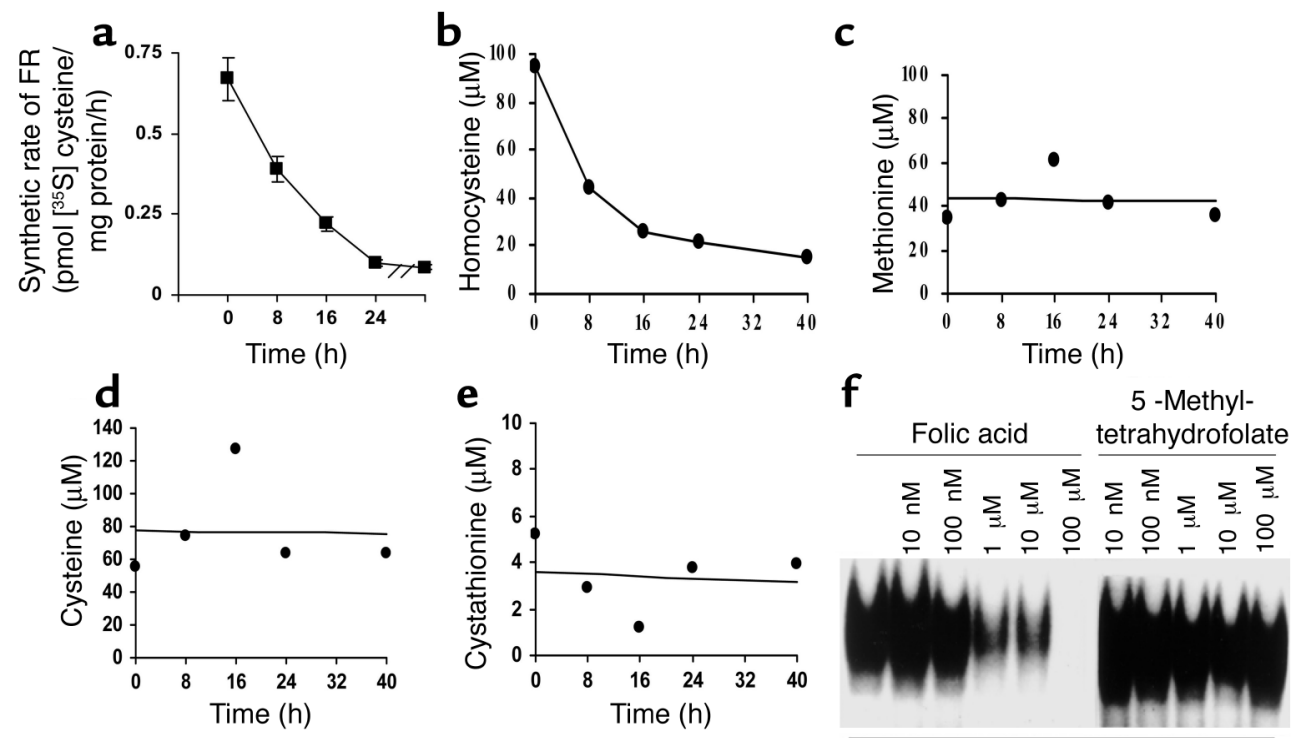

DL-Homocysteine (1 mM)

\section{Figure 7}

Effect of acute reversal of folate deficiency on HeLa-IU $-L F$ cells by high-folate media on the parameters of FR biosynthesis, homocysteine concentration, and RNA cis-element-hnRNP E1 interactions. (a-e) Changes in the FR synthesis rate (a) and concentrations of total homocysteine (b), methionine (c), total cysteine (d), and cystathionine (e) in the growth media as a function of time after placement of HeLa-IU $U_{1}-L F$ cells in high-folate (folic acid) media. (a) The value for changes in FR synthetic rate in HeLa-IU $1-L F$ cells at various time points is shown (squares). (f) Effect of folic acid and 5-methyltetrahydrofolate on the interaction of 18-base cis-element from the 5'-UTR of FR- $\alpha$ mRNA and the 43-kDa hnRNP E1. [ $\left.{ }^{32} \mathrm{P}\right]$ cis-element $(10,000 \mathrm{cpm})$ was allowed to react with $20 \mu \mathrm{g}$ dialyzed S-100 fraction from HeLa-IU ${ }_{1}-H F$ cells that was supplemented with $1 \mathrm{mM}$ dl-homocysteine and increasing concentrations of folic acid or 5-methyl-tetrahydrofolate. RNA-protein complexes were separated by native PAGE, followed by autoradiography. 


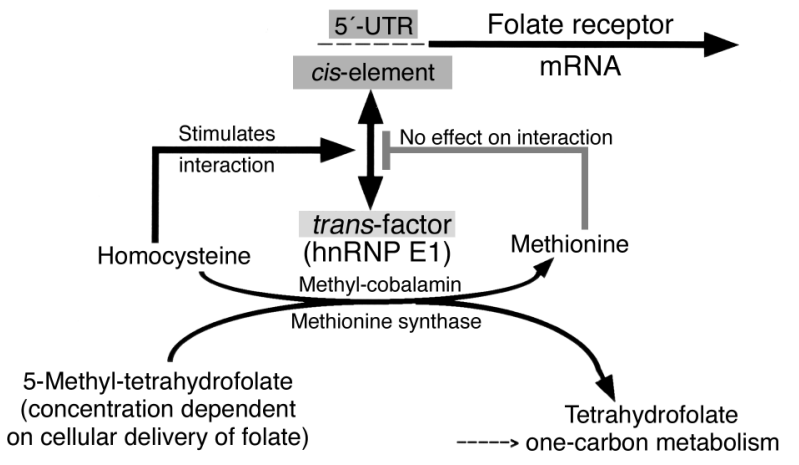

Figure 8

Model to account for the linkage between perturbed folate metabolism and coordinated translational regulation of folate receptors. Reduced folate availability results in inactivation of methionine synthase (EC 2.1.1.3) with homocysteine build-up. Homocysteine increases the interaction of the FR- $\alpha$ mRNA cis-element and specific trans-factor/hnRNP E1 to stimulate FR synthesis and upregulation. Folate repletion reactivates methionine synthase (EC 2.1.1.3), which converts homocysteine to methionine. Methionine has no effect on the RNA-protein interaction that leads to reduced FR synthesis. The direct effect of pharmacological concentrations of folic acid in quenching RNA-protein interactions is not shown.

\section{Discussion}

Model of translational upregulation of FRs in folate deficiency. Collectively, our data strongly suggest the following model for translational regulation of FRs based on the availability of folate (Figure 8): With depletion of cellular 5-methyl-tetrahydrofolate, the enzyme methionine synthase (EC 2.1.1.3) is inactivated, leading to a progressive build-up of homocysteine (in proportion to the severity of folate deficiency) (Figure 3). The progressive accumulation of homocysteine triggers the interaction of the specific 43-kDa cytosolic hnRNP E1 with the 18base cis-element in the $5^{\prime}$-UTR of FR- $\alpha$ mRNA (Figure 4), which facilitates increased synthesis of FRs (Figure 2) and net upregulation of FRs (Figure 1).

Conversely, based on our experimental data (Figures 4a and 7), the most likely explanation for downregulation is that upon conversion of folic acid to 5-methyl-tetrahydrofolate, the resulting activation of methionine synthase (EC 2.1.1.3) led to progressive methylation of homocysteine to methionine. With less available homocysteine (and more methionine) there would be less RNA-protein interaction, which would lead to downregulation of FRs. This model is consistent with physiological replenishment of folate from diet and folate supplements. However, we have also identified that with nonphysiologically high doses of folic acid, such as those that can be achieved following parenteral replenishment of folic acid, there is an independent direct effect of folic acid in reducing homocysteine-induced RNA-protein interaction that would also contribute to downregulation of FRs.

This model is entirely consistent with maintenance of folate homeostasis, and somewhat resembles other systems in which translational control of regulation involves modulation of the interaction of cis-elements and trans-factors by one or more physiologic or pharmacological stimuli. For example, iron modulates the interaction of an iron-responsive element-binding protein with ferritin mRNA, transferrin receptor mRNA, and erythroid 5-aminolevulinate synthase mRNA (39, 40). Likewise, hypoxia, estrogen, angiotensin, and $\beta$-adrenergic agonists stimulate the interaction of erythropoietin mRNA (41), vitellogenin mRNA (42), angiotensinogen mRNA (43), and $\beta$-adrenergic receptor mRNA (44) with their respective specific mRNAbinding proteins. The regulation of $\mathrm{FR}$ is nevertheless distinct in that the major determinant of the cis-element and hnRNP E1 interaction leading to translational upregulation of FRs is not the receptor ligand (folate) but the concentration of a key metabolite, homocysteine, which bears an inverse relationship with intracellular folate levels. These findings establish a linkage between perturbed folate metabolism and coordinated regulation of FR expression.

Potential broader significance of these data. To our knowledge, the demonstration of direct effects of homocysteine on RNA-protein interaction leading to translational upregulation of a protein has no precedent. Our results could have an effect in several related areas: (a) Homocysteine could also have effects in modulating RNA-protein interactions in the physiology of other proteins involved in folate, cobalamin (vitamin $\mathrm{B}_{12}$ ), and one-carbon metabolism. Moreover, in erythroid precursors that contain genes for FR and 15-lipoxygenase and $\alpha$-globin, which encode for RNA cis-elements that can interact with hnRNP E1 $(14,45)$, folate deficiency-related accumulation of homocysteine is likely to lead to functional changes in expression of these genes during erythroid proliferation or differentiation (FRs are active during erythroid proliferation $[24,46]$, whereas 15 -lipoxygenase and $\alpha$-globin are expressed during erythroid differentiation [47]). (b) Earlier studies of iron regulation-related genes implicated the oxidation-reduction state as an important modulator of RNA-protein interactions (48-52). Our data indicate that the thiol amino acid homocysteine, which covalently binds cysteine residues to modify protein function (36), can also directly modulate RNA-protein binding to influence the translational efficiency of FR. In addition, homocysteine thiolactone, which was also active in stimulating RNA-protein interaction (Figure 4 , a and $b$ ), is incorporated into a number of proteins by acylation of side-chain amino groups of lysine residues by the activated carboxyl group of the thiolactone (53). In this context, it is therefore possible that induction of the transcription of a variety of new genes by homocysteine $(37,54-56)$ could also involve direct modulation of DNA-hnRNP E1 interactions by the thiol amino acid or its cyclic thioester. Jakubowski (57) has recently demonstrated that homocysteine bound by amide or peptide linkages (homocysteine- $N$-protein) is present in a variety of human serum proteins and that plasma homocysteine- $N$-protein is correlated with plasma total homocysteine. In view of the elevated 
homocysteine within cells during folate deficiency, our studies predict that homocysteine could (either directly or indirectly) alter the function of hnRNP E1 and increase its affinity for the cis-element. To resolve this issue, we have initiated site-directed mutagenesis of specific amino acid residues that may be involved within a putative RNA-binding pocket of hnRNP E1 (Y.S. Tang, R.A. Khan, S. Xiao, H.N. Jayaram, and A.C. Antony, unpublished observations); our preliminary data appear to support a direct effect of homocysteine on hnRNP E1. (c) Because chronic hyper-homocysteinemia is a major risk factor in a variety of occlusive vascular diseases (58-65), some neural tube defects (66-68), congenital heart defects (69), and, as demonstrated more recently, dementia and Alzheimer disease (70), the direct effects of homocysteine on RNA-protein and possibly DNA-protein interactions could have a role in the etiology and pathogenesis of these diseases (71). Moreover, since approximately $13 \%$ of homocysteine can enter cells from the extracellular media, it is possible that with significant levels of chronic hyperhomocysteinemia, as noted with congenital defects in folate and cobalamin metabolism (72), entry of the thiol intracellularly has the potential to trigger additional effects on gene transcription and/or translation. (d) Finally, because of the recent documentation of a role of FRs in mediating the cellular entry of Ebola virus (73), our demonstration that acute downregulation can occur within 24 hours of exposure to high concentrations of folic acid may be of some practical importance. Aerosolized Ebola virus can be transmitted between humans through the respiratory route. As bronchial glands and alveolar lining cells (including type I and type II pneumocytes) highly overexpress FRs (74), it is theoretically possible that rapid downregulation of FRs by folic acid may help to reduce the risk of uptake of virus among noninfected individuals (including health care personnel entering an epidemic zone).

\section{Acknowledgments}

This work was supported in part by NIH grants R01CA58919 and R01HD39295 (to A.C. Antony) and R01AG09834 (to S.P. Stabler), and a Veterans Affairs Merit Review Award (to A.C. Antony).

1. Antony, A.C. 2000. Megaloblastic anemias. In Hematology: basic principles and practice. R. Hoffman et al., editors. Churchill-Livingstone. New York, New York, USA. 446-485.

2. Antony, A.C. 1996. Folate receptors. Annu. Rev. Nutr. 16:501-521.

3. Sun, X.L., et al. 1995. Transduction of folate receptor cDNA into cervical carcinoma cells using recombinant adeno-associated virions delays cell proliferation in vitro and in vivo. J. Clin. Invest. 96:1535-1547.

4. Antony, A.C. 1992. The biological chemistry of folate receptors. Blood. 79:2807-2820

5. McHugh, M., and Cheng, Y.C. 1979. Demonstration of a high affinity folate binder in human cell membranes and its characterization in cultured human KB cells. J. Biol. Chem. 254:11312-11318.

6. Kane, M.A., et al. 1988. Influence on immunoreactive folate-binding proteins of extracellular folate concentration in cultured human cells. J. Clin. Invest. 81:1398-1406.

7. Henderson, G.B., Tsuji, J.M., and Kumar, H.P. 1988. Mediated uptake of folate by a high-affinity binding protein in sublines of L1210 cells adapted to nanomolar concentrations of folate. J. Membr. Biol. 101:247-258.

8. Jansen, G., et al. 1989. Expression of a folate binding protein in L1210 cells grown in low folate medium. Cancer Res. 49:1959-1963.
9. Sadasivan, E., and Rothenberg, S.P. 1989. The complete amino acid sequence of a human folate binding protein from $\mathrm{KB}$ cells determined from the cDNA [erratum 1990, 265:1821]. J. Biol. Chem. 264:5806-5811.

10. Hsueh, C.T., and Dolnick, B.J. 1993. Altered folate-binding protein mRNA stability in KB cells grown in folate-deficient medium. Biochem. Pharmacol. 45:2537-2545.

11. Zhu, W.Y., Alliegro, M.A., and Melera, P.W. 2001. The rate of folate receptor $\alpha(F R \alpha)$ synthesis in folate depleted CHL cells is regulated by a translational mechanism sensitive to media folate levels, while stable overexpression of its mRNA is mediated by gene amplification and an increase in transcript half-life. J. Cell. Biochem. 81:205-219.

12. Sadasivan, E., Regec, A., and Rothenberg, S.P. 2002. The half-life of the transcript encoding the folate receptor $\alpha$ in $\mathrm{KB}$ cells is reduced by cytosolic proteins expressed in folate-replete and not in folate-depleted cells. Gene. 291:149-158.

13. Sun, X.L., and Antony, A.C. 1996. Evidence that a specific interaction between an 18-base cis-element in the $5^{\prime}$-untranslated region of human folate receptor- $\alpha$ mRNA and a $46-\mathrm{kDa}$ cytosolic trans-factor is critical for translation. J. Biol. Chem. 271:25539-25547.

14. Xiao, X., et al. 2001. Isolation and characterization of a folate receptor mRNA-binding trans-factor from human placenta: Evidence favoring identity with heterogeneous nuclear ribonucleoprotein E1. J. Biol. Chem. 276:41510-41517.

15. Ostareck, D.H., et al. 1997. mRNA silencing in erythroid differentiation: hnRNP K and hnRNP E1 regulate 15-lipoxygenase translation from the $3^{\prime}$ end. Cell. 89:597-606.

16. Pillai, M.R., et al. 2003. Expression of folate receptors and heterogeneous nuclear ribonucleoprotein-E1 in women with human papillomavirusmediated transformation of cervical tissue to cancer. J. Clin. Path. 56:569-574.

17. Elwood, P.C. 1989. Molecular cloning and characterization of the human folate-binding protein cDNA from placenta and malignant tissue culture (KB) cells. J. Biol. Chem. 264:14893-14901.

18. Shen, F., Ross, J.F., Wang, X., and Ratnam, M. 1994. Identification of a novel folate receptor, a truncated receptor, and receptor type $\beta$ in hematopoietic cells: cDNA cloning, expression, immunoreactivity, and tissue specificity. Biochemistry. 33:1209-1215.

19. Kolhouse, J.F., Stabler, S.P., and Allen, R.H. 1993. Identification and perturbation of mutant human fibroblasts based on measurements of methylmalonic acid and total homocysteine in the culture media. Arch. Biochem. Biophys. 303:355-360.

20. Hultberg, B., Andersson, A., and Isaksson, A. 1995. Metabolism of homocysteine, its relation to the other cellular thiols and its mechanism of cell damage in a cell culture line (human histiocytic cell line U-937). Biochim. Biophys. Acta. 1269:6-12.

21. Jayaram, H.N., Zhen, W., and Gharehbaghi, K. 1993. Biochemical consequences of resistance to tiazofurin in human myelogenous leukemic K562 cells. Cancer Res. 53:2344-2348.

22. Sun, X.L., et al. 1999. Modulation of the cytotoxicity of $3^{\prime}$-azido-3'deoxythymidine and methotrexate after transduction of folate receptor cDNA into human cervical carcinoma: identification of a correlation between folate receptor expression and thymidine kinase activity. Cancer Res. 59:940-946.

23. Antony, A.C., Kane, M.A., Portillo, R.M., Elwood, P.C., and Kolhouse, J.F. 1985. Studies of the role of a particulate folate-binding protein in the uptake of 5-methyltetrahydrofolate by cultured human KB cells. J. Biol. Chem. 260:14911-14917.

24. Antony, A.C., et al. 1991. Megaloblastic hematopoiesis in vitro. Interaction of anti-folate receptor antibodies with hematopoietic progenitor cells leads to a proliferative response independent of megaloblastic changes. J. Clin. Invest. 87:313-325.

25. Sambrook, J., Fritsch, E.F., and Maniatis, T. 1989. Molecular cloning: a laboratory manual. 2nd edition. Cold Spring Harbor Laboratory Press. Plainview, New York, USA. 5.33-5.56.

26. Weber, B., Horiguchi, J., Luebbers, R., Sherman, M., and Kufe, D. 1989. Posttranscriptional stabilization of c-fms mRNA by a labile protein during human monocytic differentiation. Mol. Cell Biol. 9:769-775.

27. Verma, R.S., Gullapalli, S., and Antony, A.C. 1992. Evidence that the hydrophobicity of isolated, in situ, and de novo-synthesized native human placental folate receptors is a function of glycosyl-phosphatidylinositol anchoring to membranes. J. Biol. Chem. 267:4119-4127.

28. Antony, A.C., Utley, C., Van Horne, K.C., and Kolhouse, J.F. 1981. Isolation and characterization of a folate receptor from human placenta. J. Biol. Chem. 256:9684-9692.

29. Stabler, S.P., et al. 1988. Elevation of total homocysteine in the serum of patients with cobalamin or folate deficiency detected by capillary gas chromatography-mass spectrometry. J. Clin. Invest. 81:466-474.

30. Allen, R.H., Stabler, S.P., Savage, D.G., and Lindenbaum, J. 1993. Metabolic abnormalities in cobalamin (vitamin B12) and folate deficiency. FASEB J. 7:1344-1353.

31. Savage, D.G., Lindenbaum, J., Stabler, S.P., and Allen, R.H. 1994. Sensi- 
tivity of serum methylmalonic acid and total homocysteine determinations for diagnosing cobalamin and folate deficiencies. Am. J. Med. 96:239-246.

32. Stabler, S., Allen, R., Savage, D., and Lindenbaum, J. 1991. Diagnosis of cobalamin deficiency. Blood. 77:1854.

33. Luhrs, C.A. 1991. The role of glycosylation in the biosynthesis and acquisition of ligand-binding activity of the folate-binding protein in cultured KB cells. Blood. 77:1171-1180.

34. Peters, B.P., et al. 1983. The use of drugs to dissect the pathway for secretion of the glycoprotein hormone chorionic gonadotropin by cultured human trophoblastic cells. J. Biol. Chem. 258:14505-14515.

35. Banerjee, R.V., and Matthews, R.G. 1990. Cobalamin-dependent methionine synthase. FASEB J. 4:1450-1459.

36. Hajjar, K.A., et al. 1998. Tissue plasminogen activator binding to the annexin II tail domain. Direct modulation by homocysteine. J. Biol. Chem. 273:9987-9993.

37. Chacko, G., Ling, Q., and Hajjar, K.A. 1998. Induction of acute translational response genes by homocysteine. Elongation factors- $1 \alpha,-\beta$, and $-\delta$. J. Biol. Chem. 273:19840-19846.

38. Antony, A.C., Kane, M.A., Krishnan, S.R., Kincade, R.S., and Verma, R.S. 1989. Folate (pteroylglutamate) uptake in human red blood cells, erythroid precursors and $\mathrm{KB}$ cells at high extracellular folate concentrations. Evidence against a role for specific folate-binding and transport proteins. Biochem. J. 260:401-411.

39. Constable, A., Quick, S., Gray, N.K., and Hentze, M.W. 1992. Modulation of the RNA-binding activity of a regulatory protein by iron in vitro: switching between enzymatic and genetic function? Proc. Natl. Acad. Sci. U. S. A. 89:4554-4558.

40. Melefors, O., et al. 1993. Translational control of 5-aminolevulinate synthase mRNA by iron-responsive elements in erythroid cells. J. Biol. Chem. 268:5974-5978

41. Rondon, I.J., et al. 1991. Hypoxia up-regulates the activity of a novel erythropoietin mRNA binding protein. J. Biol. Chem. 266:16594-16598.

42. Dodson, R.E., and Shapiro, D.J. 1994. An estrogen-inducible protein binds specifically to a sequence in the $3^{\prime}$ untranslated region of estrogenstabilized vitellogenin mRNA. Mol. Cell Biol. 14:3130-3138.

43. Klett, C., Bader, M., Ganten, D., and Hackenthal, E. 1994. Mechanism by which angiotensin II stabilizes messenger RNA for angiotensinogen. Hypertension. 23:I120-I125.

44. Huang, L.Y., Tholanikunnel, B.G., Vakalopoulou, E., and Malbon, C.C. 1993. The $M_{r} 35,000 \beta$-adrenergic receptor mRNA-binding protein induced by agonists requires both an AUUUA pentamer and U-rich domains for RNA recognition. J. Biol. Chem. 268:25769-25775.

45. Antony, A.C., Tang, Y.-S., Xiao, X., Mackins, J.Y., and Stabler, S.P. 2001. Mechanism of translational up-regulation of folate receptors (FR). 20th Annual Convention of the Indian Association for Cancer Research (Abstract Book), Jan. 19-21, 2001. Ahmedabad, Gujerat State, India.

46. Antony, A.C., et al. 1987. Effect of perturbation of specific folate receptors during in vitro erythropoiesis. J. Clin. Invest. 80:1618-1623.

47. Ostareck-Lederer, A., Ostareck, D.H., and Hentze, M.W. 1998. Cytoplasmic regulatory functions of the $\mathrm{KH}$-domain proteins hnRNPs $\mathrm{K}$ and E1/E2. Trends Biochem. Sci. 23:409-411.

48. Rouault, T.A., Hentze, M.W., Caughman, S.W., Harford, J.B., and Klausner, R.D. 1988. Binding of a cytosolic protein to the iron-responsive element of human ferritin messenger RNA. Science. 241:1207-1210.

49. Hentze, M.W., Rouault, T.A., Harford, J.B., and Klausner, R.D. 1989. Oxidation-reduction and the molecular mechanism of a regulatory RNAprotein interaction. Science. 244:357-359.

50. Lin, J.J., et al. 1990. Derepression of ferritin messenger RNA translation by hemin in vitro. Science. 247:74-77.

51. Goessling, L.S., Daniels-McQueen, S., Bhattacharyya-Pakrasi, M., Lin, J.J., and Thach, R.E. 1992. Enhanced degradation of the ferritin repres- sor protein during induction of ferritin messenger RNA translation. Science. 256:670-673

52. Rouault, T.A., Stout, C.D., Kaptain, S., Harford, J.B., and Klausner, R.D. 1991. Structural relationship between an iron-regulated RNA-binding protein (IRE-BP) and aconitase: functional implications. Cell 64:881-883

53. Jakubowski, H. 1997. Metabolism of homocysteine thiolactone in human cell cultures. Possible mechanism for pathological consequences of elevated homocysteine levels. J. Biol. Chem. 272:1935-1942.

54. Lubec, B., et al. 1996. Homocysteine increases cyclin-dependent kinase in aortic rat tissue. Circulation. 94:2620-2625.

55. Tsai, J.C., et al. 1996. Induction of cyclin A gene expression by homocysteine in vascular smooth muscle cells. J. Clin. Invest. 97:146-153.

56. Kokame, K., Kato, H., and Miyata, T. 1996. Homocysteine-respondent genes in vascular endothelial cells identified by differential display analysis. GRP78/BiP and novel genes. J. Biol. Chem. 271:29659-29665.

57. Jakubowski, H. 2002. Homocysteine is a protein amino acid in humans. Implications for homocysteine-linked disease. J. Biol. Chem. 277:30425-30428.

58. Graham, I.M., et al. 1997. Plasma homocysteine as a risk factor for vascular disease. The European Concerted Action Project. JAMA. 277:1775-1781

59. Mayer, E.L., Jacobsen, D.W., and Robinson, K. 1996. Homocysteine and coronary atherosclerosis. J. Amer. Coll. Cardiol. 27:517-527.

60. Aronow, W.S., Ahn, C., and Schoenfeld, M.R. 1997. Association between plasma homocysteine and extracranial carotid arterial disease in older persons. Am. J. Cardiol. 79:1432-1433.

61. Dennis, V.W., and Robinson, K. 1996. Homocysteinemia and vascular disease in end-stage renal disease. Kidney Int. Suppl. 57:S11-S17.

62. Robinson, K., et al. 1996. Hyperhomocysteinemia confers an independent increased risk of atherosclerosis in end-stage renal disease and is closely linked to plasma folate and pyridoxine concentrations. Circulation. 94:2743-2748.

63. Konecky, N., et al. 1997. Correlation between plasma homocyst(e)ine and aortic atherosclerosis. Am. Heart J. 133:534-540.

64. Refsum, H., Ueland, P.M., Nygard, O., and Vollset, S.E. 1998. Homocysteine and cardiovascular disease. Annu. Rev. Med. 49:31-62.

65. Goddijn-Wessel, T.A., et al. 1996. Hyperhomocysteinemia: a risk factor for placental abruption or infarction. Eur. J. Obstet. Gynecol. Reprod. Biol. 66:23-29.

66. Whitehead, A.S., et al. 1995. A genetic defect in 5,10 methylenetetrahy drofolate reductase in neural tube defects. Quart. J. Med. 88:763-766.

67. van der Put, N.M., et al. 1995. Mutated methylenetetrahydrofolate reductase as a risk factor for spina bifida. Lancet. 346:1070-1071.

68. Posey, D.L., Khoury, M.J., Mulinare, J., Adams, M.J., Jr., and Ou, C.Y 1996. Is mutated MTHFR a risk factor for neural tube defects? Lancet 347:686-687.

69. Rosenquist, T.H., Ratashak, S.A., and Selhub, J. 1996. Homocysteine induces congenital defects of the heart and neural tube: effect of folic acid. Proc. Natl. Acad. Sci. U. S. A. 93:15227-15232.

70. Seshadri, S., et al. 2002. Plasma homocysteine as a risk factor for dementia and Alzheimer's disease. N. Engl. J. Med. 346:476-483.

71. Antony, A.C., and Hansen, D.K. 2000. Hypothesis: folate-responsive neural tube defects and neurocristopathies. Teratology. 62:42-50.

72. Rosenblatt, D.S., and Whitehead, V.M. 1999. Cobalamin and folate deficiency: acquired and hereditary disorders in children. Semin. Hematol. 36:19-34

73. Chan, S.Y., et al. 2001. Folate receptor-alpha is a cofactor for cellular entry by Marburg and Ebola viruses. Cell. 106:117-126.

74. Weitman, S.D., et al. 1992. Cellular localization of the folate receptor: potential role in drug toxicity and folate homeostasis. Cancer Res. 52:6708-6711. 